$1-1-2017$

\title{
Public Participation in Nonlegislative Rulemaking
}

Aram A. Gavoor

Daniel Miktus

Follow this and additional works at: https://digitalcommons.law.villanova.edu/vlr

Part of the Law Commons

\section{Recommended Citation}

Aram A. Gavoor \& Daniel Miktus, Public Participation in Nonlegislative Rulemaking, 61 Vill. L. Rev. 759 (2017).

Available at: https://digitalcommons.law.villanova.edu/vlr/vol61/iss5/1

This Article is brought to you for free and open access by Villanova University Charles Widger School of Law Digital Repository. It has been accepted for inclusion in Villanova Law Review by an authorized editor of Villanova University Charles Widger School of Law Digital Repository. 


\section{Public Participation in Nonlegislative Rulemaking}

Cover Page Footnote

Law; Administrative Law 


\title{
VILLANOVA LAW REVIEW
}

VOLUME 61

Number 5

\section{Articles}

\section{PUBLIC PARTICIPATION IN NONLEGISLATIVE RULEMAKING}

\author{
Aram A. Gavoor* \\ DANiEl MikTus**
}

\section{INTRODUCTION}

$\mathrm{T}$

HE present state of administrative law allows for members of the public to be the subject of arbitrary governmental enforcement proceedings based on regulations that are promulgated by an unelected and semiaccountable government bureaucracy. Many of these rules are of a nonlegislative nature, issued without advance notice to the public or public participation. There is no clear authority to facially challenge the legality of these rules through the ability to petition. Even if Article III review is available, the federal courts apply inconsistent standards of review.

Federal lawmaking must be based on congressional enactments or administrative interpretations of congressional enactments. ${ }^{1}$ The Administrative Procedure Act (APA) provides general authorization for administrative agencies to promulgate legally binding regulations. ${ }^{2}$ To ensure that individuals remain able to participate in the legislative process when Congress delegates lawmaking authority to agencies, the APA requires that agencies follow specific procedures when issuing legally binding rules, including publication of any proposed rule, opportunity for public comment on the rule, and publication of the rule prior to its effective date. ${ }^{3}$

This same mandate, however, exempts agencies' "interpretative rules, general statements of policy, and rules of agency organization, procedure,

* Professorial Lecturer of Law, The George Washington University Law School. Thanks to Dick Pierce, Lisa Schenck, and Steven Schlossberg for their guidance and advice. The views expressed in this article are solely the views of the authors.

** J.D., George Mason University, B.A., Saint Joseph's University.

1. See U.S. Const. art. I; Whitman v. Am. Trucking Ass'ns, Inc., 531 U.S. 457, 472 (2001); J.W. Hampton, Jr., \& Co. v. United States, 276 U.S. 394, 408-09 (1928).

2. See Administrative Procedure Act, Pub. L. No. 79-404, 60 Stat. 237 (1946) (current version codified at 5 U.S.C. $\$ \S 551-559$ (2012)).

3. See 5 U.S.C. § 553; see also generally U.S. ConsT. art. I-II. 
Villanova Law Review, Vol. 61, Iss. 5 [2017], Art. 1

[and] practice" (collectively, nonlegislative rules) from these public participation procedures. ${ }^{4}$ Although nonlegislative rules are exempt from these requirements because they do not carry "the force of law," agencies nonetheless tend to promulgate nonlegislative rules that are of a legislative nature that impart legal duties and impose legal consequences on individuals. ${ }^{6}$ This agency practice is antithetical to the system of representative government and leaves individuals with no opportunity to participate in the promulgation of binding regulations. The problem is exacerbated upon considering the quantity of regulations federal administrative agencies promulgate, how agencies are increasingly choosing to issue nonlegislative rules over legislative rules, and the fact that the Supreme Court has signaled a willingness to apply Cheuron deference to longstanding nonlegislative rules. ${ }^{7}$

4. See 5 U.S.C. $§ 553(\mathrm{~b})(3)$ (A).

5. See William Funk, When Is a "Rule" a Regulation? Marking a Clear Line Between Nonlegislative Rules and Legislative Rules, 54 Admin. L. Rev. 659, 659-60 (2002) ("Legislative rules have the force and effect of law. Nonlegislative rules do not.").

6. See Robert A. Anthony, Interpretive Rules, Policy Statements, Guidances, Manuals, and the Like-Should Federal Agencies Use Them to Bind the Public?, 41 Duke L.J. 1311, 1332-55 (1992) (listing numerous legal challenges to nonlegislative rules used to initiate enforcement proceedings against individuals). For a recent newsworthy example of such a nonlegislative rule that can be used, at least in part, to initiate enforcement proceedings, see U.S. DeP'T of LABor, WAge \& Hour Div., Fact Sheet \#71: Internship Programs Under the Fair Labor Standards Act (Apr. 2010), http://www.dol.gov/whd/regs/compliance/whdfs71.pdf [https://perma.cc/ K8MG-N24N]; see also, e.g., Wolfe v. AGV Sports Grp., Inc., Civil No. CGB 14-1601, 2014 WL 5595295 (D. Md. Nov. 3, 2014); Xuedan Wang v. Hearst Corp., No. 12 CV 793(HB), 2013 WL 3326650 (S.D.N.Y. June 27, 2013); Todd D. Rakoff, The Choice Between Formal and Informal Modes of Administrative Regulation, 52 Admin. L. Rev. 159, 167 (2000) (observing nonlegislative rules still establish "the law for all those unwilling to pay the expense, or suffer the ill-will of challenging the agency in court").

7. See, e.g., Barnhart v. Walton, 535 U.S. 212, 218-19 (2002) (citing Chevron U.S.A. Inc., v. Natural Res. Def. Council, Inc., 467 U.S. 837, 842-43 (1984)); United States v. Mead Corp., 533 U.S. 218 (2001); NationsBank of N.C., N.A. v. Variable Annuity Life Ins. Co., 513 U.S. 251 (1995); see also Maeve P. Carey, Cong. Research Serv., R43056, Counting Regulations: An Overview of Rulemaking, Types of Federal Regulations, and Pages in the Federal Register 1, 6, 19 (2015) [hereinafter Counting Regulations] (noting "the number of final rules published each year is generally in the range of 2,500-4,500" and that in most recent year for which data is available, 2014, agencies published 3,554 final rules in Federal Register, spanning 24,861 pages). In contrast, the 113th Congress, sitting between January 2013 and 2015, enacted just 296 laws and 663 resolutions. See Statistics and Historical Comparison, GOvTRACK.us, https://www.govtrack.us/congress/bills/statistics [https://perma.cc/CJE7-MV93] (last visited December 5, 2015). However, of the 3,554 final rules issued by agencies in 2014, only eighty were considered "major rules," as defined by the Congressional Review Act. See 5 U.S.C. § 804(2) (2012); Counting Regulations, supra, at 7-8; see also Peter L. Strauss, Publication Rules in the Rulemaking Spectrum: Assuring Proper Respect for an Essential Element, 53 Admin. L. Rev. 803, 805 (2001) (noting that between 1975 and 1977, Nuclear Regulatory Commission issued guidance documents "in a volume dwarfing the regulations"); Connor N. Raso, Note, Strategic or Sincere? Analyzing 
A curative, yet underutilized, salve for this agency behavior lies in the petitioning provision of APA $\S 553$ (e) (the Petition Provision or $\$ 553(\mathrm{e})$ ), which requires agencies to give individuals "the right to petition [the agency] for the issuance, amendment, or repeal of a rule." ${ }^{8}$ While the law is well tread on the point that agencies must permit interested persons to submit petitions regarding legislative rules, courts and commentators disagree as to whether agencies must accept and adjudicate petitions for nonlegislative rules from the regulated public. ${ }^{9}$ There is no consensus regarding which procedures, if any, an agency must follow when it receives a petition either for legislative or nonlegislative rulemaking under $\S 553(\mathrm{e})$. If agencies are either not required to accept petitions regarding nonlegislative rules or may elect to simply ignore or perpetually delay adjudicating such petitions, the outcome would be a regulatory system where agencies could promulgate rules, even those with the force of law, without public participation. The negative effect of this repetitious scenario is amplified by the fact that there is no clear right of judicial review of certain agency actions regarding petitions. Even when such review is available, the federal courts employ inconsistent standards to evaluate both agency inaction and unreasonable delay in adjudicating a petition. This was not the intention of the Framers of the Constitution or the drafters of the APA, both of whom envisioned a system where the public should participate in crafting federal law, and where the courts should be the final arbiter of the legality of those laws.

This Article examines three aspects of the APA's Petition Provision. First, it analyzes how agencies can effectively prevent the public from playing any role in the promulgation of nonlegislative administrative rules. It explains that the language, structure, context, and legislative history of $\S 553$ (e) uniformly provide that individuals must be permitted to petition administrative agencies for the enactment, amendment, or repeal of all informal rules of both a legislative and nonlegislative nature.

Next, it analyzes how agencies vary in their handling of $\S 553$ (e) petitions, frustrating the goal of encouraging procedural uniformity in agency rulemaking. ${ }^{10}$ It argues that Congress intended that agencies would con-

Agency Use of Guidance Documents, 119 YAle L.J. 782, 785 (2010) ("Guidance documents greatly outnumber legislative rules .....").

8. See 5 U.S.C. $§ 553(\mathrm{e})$.

9. For an argument that APA $\S 553(\mathrm{e})$ applies to both legislative and nonlegislative rules, see Mark Seidenfeld, Substituting Substantive for Procedural Review of Guidance Documents, 90 Tex. L. Rev. 331 (2011). For an argument that APA $\S 553(\mathrm{e})$ applies only to legislative rules, see Nina A. Mendelson, Regulatory Beneficiaries and Informal Agency Policymaking, 92 Cornell L. Rev. 397 (2007).

10. Because the APA does not contain explicit instructions for agency consideration and responses, agency practice varies considerably. See Administrative Conference of the United States, Recommendation 86-6: Petitions for Rulemaking 1 (Dec. 4, 1986), available at http:/ /www.acus.gov/sites/default/files/ documents/86-6.pdf [https://perma.cc/JJS2-KNBT] [hereinafter ACUS RECOMMENDATION 86-6]. However, the Seventh Circuit has held that, because "[t]he APA does not detail procedures for petitions," an agency "does not violate the APA by 
Villanova Law Review, Vol. 61, Iss. 5 [2017], Art. 1

sider and respond to all petitions. Moreover, agencies are required to adjudicate such petitions, either by granting or denying the relief requested without unreasonable delay. Third, it explores whether and under what circumstances agency inaction, unreasonable delay, and denials of rulemaking petitions are subject to Article III review. It details the often inconsistent standards of review employed by the federal courts when analyzing agency inaction and unreasonable delay. It argues that courts should employ a consistent standard of review, the D.C. Circuit's TRAC test, when analyzing alleged agency inaction and unreasonable delay. It observes that the issue of review of agency denials of rulemaking petitions is complex, though such review should be available in limited circumstances.

Critics suggest that adopting these suggestions will divert scarce resources from important agency goals, ${ }^{11}$ lead to the issuance of irrational rules that are lacking, and sometimes even at odds with, expert knowledge, ${ }^{12}$ and increase the likelihood of "industry capture" of agencies. ${ }^{13}$ Yet, there is no evidence that permitting nonlegislative rulemaking petitions or requiring agencies to respond to petitions will significantly increase the number of petitions received by agencies. There is similarly no evidence to suggest that petition-initiated rules tend to address any less important issues than those initiated by agencies. At least one study on the effects of regulatory capture suggests that capture is not as common or likely as it once was thought. ${ }^{14}$ Petitions can lead agencies to address mat-

not having detailed procedures governing petitions.” See Wis. Elec. Power Co. v. Costle, 715 F.2d 323, 328 (7th Cir. 1983); see also Wong Yang Sung v. McGrath, 339 U.S. 33, 41 (1950), superseded by statute, Immigration and Nationality Act of 1952, Pub. L. No. 82-414, 66 Stat. 163, as stated in Ardestani v. Immigration \& Naturalization Serv., 502 U.S. 129 (1991); 1 C.F.R. § 305.86-6 (1986) ("An Administrative Conference study of agency rulemaking petition procedures and practices found that while most agencies with rulemaking power have established some procedures governing petitions for rulemaking, few agencies have established sound practices in dealing with petitions or responded promptly to such petitions.").

11. See Reeve T. Bull, Building a Framework for Governance: Retrospective Review and Rulemaking Petitions, 67 Admin. L. Rev. 265, 294, 301 (2015) (noting "the commonly held belief that petitions tend to divert agencies' attention from more important issues and waste limited agency resources"); see also Eric Biber \& Berry Brosi, Officious Intermeddlers or Citizen Experts? Petitions and Public Production of Information in Environmental Law, 58 UCLA L. Rev. 321, 323-24 (2010) (noting "an overly generous petition process is blamed for the near demise of the Consumer Product Safety Commission (CPSC) in the 1970s").

12. See Biber \& Brosi, supra note 11, at 324 ("[O]verly broad public participation can lead to irrational regulation that is inconsistent with an expert assessment ....").

13. See Bull, supra note 11, at 287; see also Biber \& Brosi, supra note 11, at 331 (“[T] he scholarly literature portrays a well-intentioned public participation toolthe petition-as easily manipulated to undermine the very regulatory programs that it was intended to benefit.").

14. Rather, one study provided evidence that individual participation either had no effect or had very little effect on agency priorities, the quality of rules issued, or the occurrence of agency capture. See Biber \& Brosi, supra note 11, at 
ters that they had previously abdicated. ${ }^{15}$ Accordingly, there is either no evidence to support these criticisms, or there is countervailing evidence suggesting that they are unfounded. ${ }^{16}$

The dramatic growth of administrative agencies and the increase in rulemaking is, in part, a response to an increasingly complex set of problems. ${ }^{17}$ In light of the expansion of administrative power, it is acutely important for the public to have a say in the rules that agencies are producing, and to have a reasonable means of seeking facial redress of such rules and the procedures used to promulgate them. The Constitution and the APA amply demonstrate the value that the Framers and Congress respectively placed on public participation in the creation of federal law and the role of the judiciary in reviewing federal law. ${ }^{18}$ Because nonlegislative

364 (analyzing rules promulgated by U.S. Fish and Wildlife Service and surmising that "there is no reason to conclude that widespread use of petitions will necessarily result in diverting an agency fundamentally from a rational or systematic agenda-setting process-even when the process is dominated by one particular viewpoint or 'special interest'"). The study noted that petitions seemed even better at identifying at-risk species that would cost little to restore. But see David Moss \& Daniel Carpenter, Conclusion: A Focus on Evidence and Prevention, in Preventing Regulatory Capture: Special Interest Influence and How to Limit It 451, 452 (David Moss \& Daniel Carpenter eds., 2013) (suggesting while empirical evidence regarding regulatory capture remains scarce, it is becoming less so, and that " $[\mathrm{t}]$ he old Stiglerian notion of a fully captured regulator is most likely a rarity, if it exists at all. In fact, in recent years, the most searching analyses have cast doubt on some of the most celebrated cases of Stiglerian capture"); Ernesto Dal Bó, Regulatory Capture: A Review, 22 Oxford Rev. Econ. Pol'y 203, 220 (2006) ("The empirical evidence on the causes and consequences of regulatory capture is scarce."); David Thaw, Enlightened Regulatory Capture, 89 WAsH. L. REv. 329, 331 (2014) (" $[\mathrm{E}] \mathrm{mpirical}$ results demonstrate many examples of regulatory capture generating results contrary to the public interest ....").

15. See Biber \& Brosi, supra note 11, at 323.

16. Even if adopting these recommendations would require additional agency resources, the means justify the ends. See Sidney A. Shapiro \& Richard W. Murphy, Eight Things Americans Can't Figure out About Controlling Administrative Power, 61 ADmIN. L. REv. 5, 13 (2009) ("In a democracy, it makes sense to look for ways for affected parties to participate in the creation of governing norms both because (a) democracy presupposes that transparency and participation are good things in themselves; and (b) one might reasonably hope that exposing agency proposals to informed comment would, generally speaking, improve agency rulemaking.").

17. See Joanna L. Grisinger, The Unwieldy American State: Administrative Politics Since the New Deal 59 (2012) ("The act allowed reformers to offer a coherent approach to the dozens of agencies and commissions, each of which possessed its own messy and complicated history, institutional structure, and political context."); see also City of Arlington v. FCC, 133 S. Ct. 1863, 1879 (2013) (Roberts, C.J., dissenting) (citing Talk America, Inc. v. Mich. Bell Tel. Co., 131 S. Ct. 2254, 2266 (2011); Sackett v. EPA, 132 S. Ct. 1367, 1374 (2012)) (“[T] he danger posed by the growing power of the administrative state cannot be dismissed."); Cynthia R.S. Schiesswohl, Judicial Autonomy in the Immigration Adjudicatory System, 21 U. DAYTON L. Rev. 743, 748 (1996) (quoting Lawrence Lessig \& Cass R. Sunstein, The President and the Administration, 94 Colum. L. Rev. 1, 85-86 (1994)).

18. See Alan B. Morrison, Administrative Agencies Are Just Like Legislatures and Courts—Except When They're Not, 59 Admin. L. Rev. 79, 92 (2007) (“APA rulemaking as supplemented by judicial review over the procedural and substantive aspects of a 
Villanova Law Review, Vol. 61, Iss. 5 [2017], Art. 1

rules were not intended to carry the force of law, ${ }^{19}$ courts should rely on the language, structure, and legislative history of the APA to uphold the right to petition for the issuance, amendment, or repeal of all rules. A similar inquiry concludes that the APA requires agency adjudication of every petition submitted under $\$ 553(\mathrm{e})$, and that it provides for judicial review when agencies fail to act on, or unreasonably delay in, adjudicating a petition. Courts should uniformly utilize the D.C. Circuit's TRAC test when analyzing inaction or unreasonable delay claims. Though generally unavailable, courts should conclude that judicial review of agency denial of a rulemaking petition is not per se unreviewable.

\section{The Administrative Procedure Act and Rulemaking}

The Petition Provision of the APA, $\$ 553(\mathrm{e})$, was intended to assuage at least two of Congress's main concerns during the pre-1946 administrative state. ${ }^{20}$ For that reason, it is important to examine the conditions and concerns that led Congress (among others) to pursue sweeping regulatory reform. The APA has been referred to as the "bill of rights for the new regulatory state." 21 It set the rules for interactions among agencies, individuals, and courts in the regulatory arena. ${ }^{22}$ A durable statute, it has seldom been revised, receiving only three substantial amendments since its enactment. ${ }^{23}$ The statute was the legislative outcome of the "nation's deci-

final rule does, as a practical matter, compensate for the absence of political checks that are a central feature of the legislative process.").

19. See Robert A. Anthony, A Taxonomy of Federal Agency Rules, 52 Admin. L. REv. 1045, 1047 (2000) ("[A]lthough it does not have the force of law, the new position laid down in such a document will often have practical binding effect upon private parties."); Seidenfeld, supra note 9, at 345 ("Often, however, agencies will adopt policy statements or interpretive rules that in practice bind regulated entities ....").

20. See James Hunnicutt, Note, Another Reason to Reform the Federal Regulatory System: Agencies' Treating Nonlegislative Rules as Binding Law, 41 B.C. L. Rev. 153, 153-54 (1999) ("Congress passed the APA to foster clarity, uniformity and public participation in the administrative state.").

21. See George B. Shepherd, Fierce Compromise: The Administrative Procedure Act Emerges from New Deal Politics, 90 Nw. U. L. Rev. 1557, 1558 (1996); see also Administrative Procedure Act, Pub. L. No. 79-404, 237 (1946).

22. See Shepherd, supra note 21, at 1558 ("[T] he APA established the fundamental relationship between regulatory agencies and those whom they regulate ....").

23. See William H. Allen, The Durability of the Administrative Procedure Act, 72 VA. L. Rev. 235, 236 (1986) (noting substantive amendments include Freedom of Information Act in 1966, Privacy Act in 1974, and Government in the Sunshine Act in 1976); see also Federal Administrative Procedure Sourcebook 1 (William Funk, Jeffrey S. Lubbers, \& Charles Pou, Jr., eds., 4th ed. 2008) [hereinafter ADministrative Procedure Sourcebook] (The APA, "as originally enacted, was repealed by Pub. L. No. 89-554, 80 Stat. 381 (September 6, 1966), as part of the general revision of title 5 of the United States Code. Its provisions were incorporated into the sections of title 5 ...."). Also note that a 2013 bill seeking to amend the APA did not amend the Petition Provision's language. See generally Regulatory Accountability Act, H.R. 2122, 113th Cong. (2013). 
sion to permit extensive government, but to avoid dictatorship and central planning." 24

\section{A. Administrative Law Prior to the APA}

Administrative law existed long before the APA. Congress established the first federal administrative agency, the Interstate Commerce Commission (ICC), in 1887 by enacting the Interstate Commerce Act. ${ }^{25}$ By the start of the twentieth century, Congress had created about one-third of all currently existing federal agencies, and by 1930, the number of agencies reached approximately two-thirds of today's number. ${ }^{26}$ In response, comprehensive administrative procedure reform became a prevalent issue. A 1933 American Bar Association (ABA) report found major issues with the administrative state, including the new and increasingly substantial powers in the executive branch that were not subject to judicial review. ${ }^{27}$ While the ABA report suggested possible legislative solutions such as codifying more stringent rules, authorizing greater judicial review, and establishing an administrative court, ${ }^{28}$ this first major attempt at reforming administrative law was unsuccessful, as were numerous subsequent attempts at reform. Although congressional attempts to reform administrative law appear as early as $1929^{29}$ and $1933,{ }^{30}$ the momentum for broad reform came in 1938. ${ }^{31}$ Some viewed administrative reform as a debate about

24. See Shepherd, supra note 21, at 1559.

25. See Mark F. Kightlinger, Nihilism with a Happy Ending? The Interstate Commerce Commission and the Emergence of the Post-Enlightenment Paradigm, 113 PenN ST. L. REv. 113, 130 (2008); see also Interstate Commerce Act, ch. 104, § 11, 24 Stat. 379, 383 (1887); Susannah T. French, Comment, Judicial Review of the Administrative Record in NEPA Litigation, 81 CALif. L Rev. 929, 933-34 (1993) (noting ICC was first administrative agency); CTr. For EfFective Gov't, A Brief History of Administrative Government, FOREFFECTIVEGOV.ORG, http://www.foreffectivegov.org/node/3461 [https://perma.cc/S23S-3Q6L] ("The first of these so-called economic regulatory agencies was the Interstate Commerce Commission . . . established in 1887 . ...").

26. See Christopher M. Pietruszkiewicz, Discarded Deference: Judicial Independence in Informal Agency Guidance, 74 TENN. L. Rev. 1, 19 n.127 (2006).

27. See generally Report of the Special Committee on Administrative Law, 1933 A.B.A. AnN. Rep. 408 (1933) [hereinafter 1933 Report] (noting other issues such as threat to ABA attorneys' large clients posed by administrative state and threat to livelihood of lawyers from creation of "administrative tribunals"); see also Shepherd, supra note 21, at 1571 ("The increasing importance of administrative tribunals appeared to elite lawyers to threaten the lawyers' livelihoods by diminishing the importance of lawyers and traditional lawyering.").

28. See 1933 Report, supra note 27, at 426-27.

29. See S. 5154, 70th Cong. (1929) (the Norris Bill); see also Kali Murray, First Things, First: A Principled Approach to Patent Administrative Law, 42 J. Marshall L. Rev. 29, 49 (2008).

30. See S. 1835, 73d Cong. (1933) (the Logan Bill); see also 1933 REPORT, supra note 27.

31. See Kathryn E. Kovacs, A History of the Military Authority Exception in the Administrative Procedure Act, 62 Admin. L. Rev. 673, 683 (2010) (noting that by 1938, Republicans and conservative Democrats began to gain more political ground); see 
Villanova Law Review, Vol. 61, Iss. 5 [2017], Art. 1

"the most efficient administrative procedures." ${ }^{2}$ It was actually a struggle between New Deal supporters and its opponents who feared the greater powers given to agencies. ${ }^{33}$

In 1939, President Roosevelt directed the Attorney General to establish a committee to recommend administrative reforms ${ }^{34}$ and asked Congress to postpone any legislation "until the [ ] [c]ommittee completed its report." 35 The Attorney General's Committee on Administrative Procedure's Final Report, completed in 1941, ${ }^{36}$ contained two proposed bills. ${ }^{37}$ The liberal majority bill sought to impose minimal restraints on agencies, while the conservative minority proposal contained a comprehensive "Code of Standards of Fair Administrative Procedure" and sought to impose stringent limits on agencies. ${ }^{38}$ Even after publication of the Attorney General's Final Report, Congress did not enact comprehensive administrative procedure reform for some years, instead choosing to focus efforts on the ongoing war. ${ }^{39}$

World War II played a large role in the eventual enactment of the APA. To manage the war effort properly, agencies were given "broad new powers" and "increased authority," 40 but no central rules placed any checks on the agencies' new powers. As the political influence of Democrats diminished and the war abroad became the President's main focus, President Roosevelt relented on his New Deal policies to " 'ensure industrialists' cooperation' in the war effort." ${ }^{41}$ Some believe that the President's domestic concessions may have caused congressional Republicans to simi-

also Shepherd, supra note 21, at 1586 ("In 1938 . . [t] he country was ripe for administrative procedural reform.").

32. See Shepherd, supra note 21, at 1595.

33. See Jeffrey S. Lubbers, A Guide to Federal Agency Rulemaking 4 (5th ed. 2012); see also Shepherd, supra note 21, at 1606, 1608, 1611 (noting reform proponents stressed administrative reform should include "protection of individual rights" from New Deal policies, while reform opponents believed supporters intended only to promote "big business's interests at individuals' expense").

34. See Administrative Procedure Sourcebook, supra note 23, at 1.

35. See Shepherd, supra note 21, at 1628.

36. See U. S. Attorney General's Comm. on Admin. Procedure, Final Report of Attorney General's Committee on Administrative Procedure, S. Doc. No. 77-8 (1941) [hereinafter 1941 AG's REPORT].

37. See id. at 191-216. Compare S. 674, 77th Cong. (1941), with S. 675, 77th Cong. (1941). The Attorney General's 1941 Final Report recommended including a petition provision, and Congress specifically considered this recommendation. See Administrative Procedure Act: Hearings Before the House Comm. on the Judiciary on the Subject of Federal Administrative Procedure, 79th Cong. 78 (1945); see also H.R. ReP. No. 79-1980, at 236-38, 245, 254, 258, 260, 284-85, 287 (1946); Administrative Procedure Sourcebook, supra note 23, at 2 (describing role of public in rulemaking process).

38. See 1941 AG’s Report, supra note 36, at 1-127, 191, 203-50; see also Shepherd, supra note 21, at 1633-34.

39. See Kovacs, supra note 31, at 693.

40. See Shepherd, supra note 21, at 1641 . 1643).

41. See Kovacs, supra note 31, at 694 (quoting Shepherd, supra note 21, at 
larly concede their demands for tight administrative regulations. ${ }^{42}$ Moreover, President Roosevelt appointed a large number of liberal federal judges who were "less likely" to invalidate New Deal regulations, reducing Republicans' desire for "broad judicial review" of agency action. ${ }^{43}$ These two factors increased the likelihood of congressional compromise on administrative reform. Finally, Francis Biddle, who served on the Attorney General's Committee on Administrative Procedure, then served as Attorney General from 1941 through 1945 and "helped to push reform along." 44 After unanimous passage in the House of Representatives and the Senate, on June 11, 1946, President Truman signed the APA into law. 45

In debates concerning reform, Congress acknowledged that the federal courts would be afforded broad flexibility in interpreting any eventual legislation. ${ }^{46}$ Because legislative history regarding administrative reform was scarce, ${ }^{47}$ various groups attempted to "create" legislative history by compiling a record for courts to interpret the statute, sometimes causing various reports to suggest alternative interpretations of the same provision. ${ }^{48}$ For instance, the 1945 Senate Judiciary Committee Report ${ }^{49}$ and the 1947 Attorney General's Manual on the Administrative Procedure Act ${ }^{50}$ suggested diverging explanations of the APA's original Petition Pro-

42. See id. at 694 (positing President Roosevelt's "retreat may have deflated the drive for strict administrative controls").

43. See id. President Roosevelt appointed 204 federal judges during his presidency. See Judgeship Appointments by President, U.S. CourTs, http://www.uscourts .gov/judges-judgeships/authorized-judgeships/judgeship-appointments-president [https://perma.cc/9G3Z-KEML] (last visited Dec. 12, 2015).

44. See Shepherd, supra note 21, at 1647.

45. See Arthur T. Vanderbilt, Legislative Background of the Federal Administrative Procedure Act, in The Federal Administrative Procedure Act and the Administrative Agencies 1, 12 (George Warren ed., 1947).

46. See 92 Cong. Rec. 2159 (1946) (statement of Sen. McCarran) ("Therefore, it will be the duty of the reviewing courts . . . to determine the meanings of the words and phrases used, insofar as they have not been defined in the bill itself."); William S. Jordan III, Chevron and Hearing Rights: An Unintended Combination, 61 Admin. L. Rev. 249, 313 (2009) (noting "[d] evelopments in the wake of the APA" suggest Congress did "not intend the courts to defer to agency decisions").

47. See Shepherd, supra note 21, at 1663 (discussing how legislative history did not exist because "[t]he bill had sprung not from public debate in Congress, as other bills had, but from months of private, off-the-record negotiations").

48. Compare S. ReP. No. 79-752 (1945) [hereinafter 1945 SENATE Judiciary RePORT], with U.S. Dep't of Justice, Attorney General's Manual on the Administrative Procedure Act (1947) [hereinafter 1947 AG's MANuAL]; see also Shepherd, supra note 21, at 1662-63, 1665 (noting Senate Committee interpreted bill as imposing tighter controls on agencies, whereas Attorney General believed bill simply "states existing law").

49. See 1945 Senate Judiciary Report, supra note 48.

50. See 1947 AG's Manual, supra note 48. 
Villanova Law Review, Vol. 61, Iss. 5 [2017], Art. 1

vision, $\S 4(\mathrm{~d}$ ) (the precursor to $\S 553(\mathrm{e})){ }^{51}$ While the Senate Committee Report interpreted the Petition Provision as requiring an agency either to grant or deny each petition or "undertake public rule making proceedings" for a petition, ${ }^{52}$ the Attorney General's Manual left open the possibility that an agency could simply not respond to a petition. ${ }^{53}$ This, as well as other, conflicting interpretations concerning vague APA provisions persist today.

\section{B. The Building Blocks of APA Legislative and Nonlegislative Rulemaking and the Petition Provision}

The contemporary APA contains two major parts: $\S \S 551$ through 559 , outlining general "agency procedures," and $\$ \S 701$ through 706, "dealing in general with judicial review" of agency action. ${ }^{54}$ Sections 551 through 559 are divided into two categories, rulemaking and adjudication. ${ }^{55}$ Rulemaking is defined as the "agency process for formulating, amending, or repealing a rule," 56 and a rule is "the whole or a part of an agency statement of general or particular applicability and future effect designed to implement, interpret, or prescribe law or policy or describing the organization, procedure, or practice requirements of an agency." 57 Agency rules have a similar legal effect as congressionally-enacted statutes. ${ }^{58}$ While specific types of rulemaking procedures are not explicitly delineated in the APA, courts have construed the APA as providing proce-

51. Original APA $\S 4(\mathrm{~d})$ stated that "[e]very agency shall accord any interested person the right to petition for the issuance, amendment, or repeal of a rule." See Pub. L. No. 79-404, § 4(d), 60 Stat. 237, 239 (1946).

52. See 1945 Senate Judiciary Report, supra note 48, at 201.

53. See 1947 AG's Manual, supra note 48, at 128 (stating $\S 4(d)$ "requires the reception and consideration of petitions, but does not compel an agency to undertake any rule-making procedure merely because a petition is filed"). Another such ambiguity that received conflicting interpretations pertained to whether a petition denial would be subject to judicial review. See 1945 Senate Judiciary Report, supra note 48, at 201, 230 (discussing Senate Judiciary Committee interpretation and Attorney General's Appendix interpretation).

54. See Administrative Procedure Sourcebook, supra note 23, at 2.

55. See generally 5 U.S.C. $\$ \$ 551-559$ (2012); see also LubBERs, supra note 33, at 44 ("[T] he entire Act is based upon a dichotomy between rule making and adjudication.”). For general information regarding adjudication, see John F. Stanley, Note, The "Magic Words" of § 554: A New Test for Formal Adjudication Under the Administrative Procedure Act, 56 Hastings L.J. 1067 (2005). APA 552 contains the familiar Freedom of Information Act. See 5 U.S.C. $\$ 552$ (2012).

56. 5 U.S.C. $\$ 551(5)$.

57. Id. $§ 551(4)$. But see generally Bowen v. Georgetown Univ. Hosp., 488 U.S. 204, 208-09 (1988) (holding agencies can adopt rules with retroactive application pursuant to explicit statutory authorization). For more information regarding retroactive agency rules, see Geoffrey C. Weien, Note, Retroactive Rulemaking, 30 HARv. J.L. \& Pub. Pol'y 749 (2007).

58. See Administrative Procedure Sourcebook, supra note 23, at 2-3 (stating rulemaking "regulates the future conduct of persons, through formulation and issuance of an agency statement designed to implement, interpret, or prescribe law or policy," and that "[i]t is essentially legislative in nature"); see also Morrison, supra 
dures for two separate types of rulemaking, generally referred to in the case law and literature as legislative and nonlegislative rulemaking. ${ }^{59}$

In addition to the delineation between legislative and nonlegislative rulemaking, the APA provides for two types of legislative rulemaking, formal and informal. ${ }^{60}$ Formal rulemaking is a rarely used and largely defunct method of agency statutory interpretation; under APA $\S 553$ (c), when an agency rule is "required by statute to be made on the record after opportunity for an agency hearing, sections 556 and 557 [ ] apply[,]" and a rulemaking is considered to be formal. ${ }^{61}$ It involves a "trial-type hearing" where agencies and adverse parties introduce evidence and conduct oral examinations. ${ }^{62}$

Until the late 1970s, agencies assumed that they must conduct most, if not all, rulemakings via these formal procedures. ${ }^{63}$ However, formal rulemaking was less than ideal. Generating formal rules was costly and inefficient, and formal agency rules were often unclear or contradictory. ${ }^{64}$ Moreover, agency goals became dependent upon rules generally applicable to the public at large, rather than rules that were applicable only to the parties involved in a particular formal rulemaking proceeding. ${ }^{65}$ In 1973 ,

note 18 , at 89 ("Like a statute, once a rule is in place, it must be obeyed unless a court overturns it or the agency revokes it.").

59. See, e.g., Perez v. Mortg. Bankers Ass'n, 135 S. Ct. 1199, 1203-04 (2015); Gen. Motors Corp. v. Ruckelshaus, 742 F.2d 1561, 1565 (D.C. Cir. 1984); Funk, supra note 5, at 659-60. These terms do not appear in the APA itself. See 5 U.S.C. $\S \S 551-559$.

60. See 5 U.S.C $\$ 553(c)$. Compare 5 U.S.C. $\$ 553$, with 5 U.S.C. $§ \S 556-557$.

61. See 5 U.S.C. $\$ 553(\mathrm{c})$; see also Administrative Procedure Sourcebook, supra note 23 , at 5 (stating formal rulemaking is "required only where the statute involved specifically requires an 'on the record' hearing" (citing United States v. Fla. E. Coast Ry. Co., 410 U.S. 224 (1973))).

62. See Ass'n of Nat'l Advertisers, Inc. v. FTC, 627 F.2d 1151, 1160 (D.C. Cir. 1979) (stating formal rulemaking "must include a trial-type hearing at which a 'party is entitled to present his case or defense or oral or documentary evidence, to submit rebuttal evidence, and to conduct such cross-examination as may be required for a full and true disclosure of the facts"” (quoting 5 U.S.C. \$ 556(d))). But see Amanda Swanson, 510(k) Clearance: Opportunities to Incentivize Medical Device Safety Through Comparative Effectiveness Research, 10 Ind. Health L. Rev. 117, 130 (2013) ("Although in theory these formal procedures may provide the best way to ensure affected parties are afforded due process . . . the reality is that these formal procedures are incredibly time consuming and inefficient." (citing KenNETH F. Warren, Administrative Law in the Political System 220 (2004))). Swanson provides an illustration of such inefficiency. See id. ("One hearing, which focused on whether peanut butter should contain 87.5 percent or 90 percent peanuts, produced a weighty 7,736-page transcript and lasted about nine years.").

63. See Rakoff, supra note 6, at 163 (noting that for this reason, "[d] uring the 1950 s and 1960 s, most major regulation took place through formal adjudicatory proceedings").

64. See id. (stating " $[\mathrm{t}]$ he reality was that agencies refrained from making rules they would have to justify with trial-type proof," and that "the law that could be extracted from agency decisions often proved to be vague or contradictory").

65. See id. at 163. 
Villanova Law Review, Vol. 61, Iss. 5 [2017], Art. 1

the Supreme Court held in United States v. Florida East Coast Railway Co. ${ }^{66}$ that the ICC's view that its authorizing statute required it to issue all regulations through formal rulemaking was incorrect. ${ }^{67}$ The Court concluded that the informal rulemaking procedures of $\S 553$ applied to the ICC. ${ }^{68}$ This same interpretation has been extended to most agencies, thus signaling the dominance of informal rulemaking. ${ }^{69}$

Informal rulemaking does not require the type of courtroom-style adjudications associated with formal rulemaking. ${ }^{70}$ As noted above, the APA implicitly creates two types of informal rules: legislative and nonlegislative. ${ }^{71}$ Legislative informal rules refer to those agency promulgations that are intended to have "the force and effect of law"72 and require public "notice and comment" procedures. ${ }^{73}$ Nonlegislative informal rules, which generally include agencies' "interpretive rules, general statements of policy, or rules of agency organization, procedure, or practice," 74 are not supposed to carry any force of law, ${ }^{75}$ and are exempted from public notice and comment procedures. ${ }^{76}$

With regard to informal legislative rulemaking, APA § 553(a) exempts certain subjects, including "military and foreign affairs function[s]" and agency personnel decisions, from its requirements. ${ }^{77}$ Subsection (b) provides that a notice of proposed rulemaking (NPRM) must be published in the Federal Register, and that the NPRM must describe when and where the rulemaking proceedings will take place, the "legal authority under which a

66. 410 U.S. 224 (1973).

67. See id. at 227-28.

68. See id.

69. See Rakoff, supra note 6 , at 163 (stating informal rulemaking described in Fla. E. Coast Ry. "would suffice for most agencies," and that "[t] he upshot of these developments was a surge of administrative rulemaking").

70. See generally 5 U.S.C. $\$ 553$ (2012).

71. See id. $\S 553$ (c). The APA does not label these two types of rules as such, but courts and commentators have come to refer to them this way. See Jacob E. Gersen, Legislative Rules Revisited, 74 U. CHI. L. Rev. 1705, 1710 (2007) ("The distinction between legislative rules and interpretive rules predates the APA, and the statutory text could be read to implicitly incorporate the preexisting doctrinal distinction." (footnote omitted)).

72. See Funk, supra note 5, at 659-60.

73. See 5 U.S.C. $\$ \S 553(\mathrm{~b})-(\mathrm{d})$.

74. See id. $\$ 553(\mathrm{~b})(3)(\mathrm{A})$.

75. See Funk, supra note 5, at 659-60.

76. See 5 U.S.C. $\$ 553$ (b) (3) (A) ("[T] his subsection does not apply . . . to interpretative rules, general statements of policy, or rules of agency organization, procedure, or practice . . . ."); see also Perez v. Mortg. Bankers Ass'n, 135 S. Ct. 1199, 1201 (2015) ("Because an agency is not required to use notice-and-comment procedures to issue an initial interpretive rule, it is also not required to use those procedures when it amends or repeals that interpretive rule.").

77. See 5 U.S.C. $\$ \$ 553$ (a) (1)-(2) ("This section applies, according to the provisions thereof, except to the extent that there is involved[:] (1) a military or foreign affairs function of the United States; or (2) a matter relating to agency management or personnel or to public property, loans, grants, benefits, or contracts."). 
rule is proposed . . . and either the substance of the proposed rule or a description of the substance and issues involved."78 Section 553(b) also lists two scenarios when the procedures prescribed in subsection (b) will not apply. ${ }^{79}$ An NPRM is not required before an agency adopts nonlegislative rules. ${ }^{80}$ Section 553(b)'s exception for nonlegislative rules forms the basis for the distinction between legislative informal rulemaking and nonlegislative informal rulemaking. ${ }^{81}$

Section 553(c) provides that after an agency issues an NPRM, the agency must provide "interested persons an opportunity to participate in the rule making through [the] submission of written data, views, or arguments." 82 This section creates the public comment period for proposed legislative rules and, when combined with $\$ 553(\mathrm{~b})$ 's requirement of an NPRM, forms what is known as "notice and comment rulemaking." 83 Section 553 (c)'s language is generally interpreted to exclude nonlegislative rules from the notice and comment requirement because an NPRM is not required for these types of rules by subsection (b). ${ }^{84}$ Section 553(c) then provides that after considering any relevant public comments, an agency must "incorporate in the rule[ ] adopted a concise general statement of [the rule's] basis and purpose." ${ }^{5}$ As noted above, $\$ 553$ (c) also provides the distinction between formal and informal rulemaking procedures, stating that the procedural requirements of $\S 556$ and $\S 557$, rather than $\S 553$, apply to formal rulemaking. ${ }^{86}$

78. See id. $\S \S 553(\mathrm{~b})(1)-(3)$.

79. See id. $\S \S 553(\mathrm{~b})(3)(\mathrm{A})-(\mathrm{B})$ ("Except when notice or hearing is required by statute, this subsection does not apply[:] (A) to interpretative rules, general statements of policy, or rules of agency organization, procedure, or practice; or (B) when the agency for good cause finds . . . that notice and public procedure thereon are impracticable, unnecessary, or contrary to the public interest.").

80. See id. §553(b) (3) (A).

81. Professor Jacob E. Gersen notes, however, that " $[\mathrm{t}]$ he distinction between legislative rules and interpretive rules predates the APA, and the statutory text could be read to implicitly incorporate the preexisting doctrinal distinction." See Gersen, supra note 71, at 1710 (footnote omitted).

82. See 5 U.S.C. $\$ 553(\mathrm{c})$.

83. See Cmty. Nutrition Inst. v. Young, 818 F.2d 943, 951 (D.C. Cir. 1987) (Starr, J., concurring in part and dissenting in part) ("In a sense, notice-and-comment procedures serve as a Congressionally mandated proxy for the procedures which Congress itself employs in fashioning its 'rules,' as it were, thereby insuring that agency 'rules' are also carefully crafted . . ..").

84. See 1947 AG's Manual, supra note 48, at 28 (stating subsections (a) and (c) "must be read together because the procedural requirements of subsection [(c)] apply only where notice is required by subsection (a)"); Seidenfeld, supra note 9 , at $371 \mathrm{n} .212$ ("[T] here is a consensus that the comment requirement in subsection (c) does not apply to such [guidance] documents."). Note that subsection 4(b) of the public law referred to in the Attorney General's Manual corresponds to subsection 553(c) of the APA.

85. See 5 U.S.C. $\$ 553(\mathrm{c})$.

86. See id. ("When rules are required by statute to be made on the record after opportunity for an agency hearing, sections 556 and 557 of this title apply instead of this subsection.”); United States v. Fla. E. Coast Ry. Co., 410 U.S. 224, 247 
Villanova Law Review, Vol. 61, Iss. 5 [2017], Art. 1

Section 553(d) provides that agencies must publish any "substantive rule" at least thirty days prior to it becoming effective. ${ }^{87}$ In addition, subsection (d) excludes from its coverage "interpretative rules and statements of policy." 88 Accordingly, nonlegislative rules need not be published prior to going into effect. Thus, APA $\S 553$ (b) provides the distinction between informal legislative rulemaking and nonlegislative rulemaking, also known as interpretive/interpretative, procedural, or policy statements. ${ }^{89}$ The procedural requirements of $\S 553$, including publication of an NPRM, a public notice and comment period, and publication of a rule at least thirty days prior to its effective date, do not apply to agencies' nonlegislative rules. ${ }^{90}$

Determining whether a prospective rule is a substantive legislative rule subject to $\S 553$ 's procedural requirements, or a nonlegislative rule exempt from those requirements, can be a difficult task for courts and agencies alike. ${ }^{91}$ While legislative rules are considered legally binding on persons, a violation of which can subject an individual to "civil or criminal penalties,"92 nonlegislative rules are not considered legally binding in that they do not impose legal obligations on individuals. ${ }^{93}$ Nonlegislative rules "function largely as guidance documents," providing the public, agency personnel, and courts with an idea of how a certain law "should be interpreted." ${ }^{4}$ They can also specify how the agency "intends . . . to exercise

(1973) (Douglas \& Stewart, JJ., dissenting) (stating $§ 556$ applies when rule is statutorily required to be made on record and after hearing).

87. See 5 U.S.C. $\$ 553(\mathrm{~d})$.

88. See id. $\$ 553(\mathrm{~d})(2)$.

89. See id. $\$ 553(\mathrm{~b})(3)(\mathrm{A})$.

90. See id. $\S \S 553(\mathrm{~b})(3)(\mathrm{A}),(\mathrm{c}),(\mathrm{d})(1)-(2)$.

91. See Gersen, supra note 71 , at 1705 ("The distinction between legislative rules and nonlegislative rules is one of the most confusing in administrative law.").

92. See William Funk, A Primer on Nonlegislative Rules, 53 Admin. L. Rev. 1321, 1322 (2001) ("[V]iolations of these rules can subject a person to civil or criminal penalties."); see also Nat'l Mining Ass'n v. McCarthy, 758 F.3d 243, 251 (D.C. Cir. 2014) ("An agency action that purports to impose legally binding obligations or prohibitions on regulated parties-and that would be the basis for an enforcement action for violations of those obligations or requirements-is a legislative rule.”); Seidenfeld, supra note 9, at 334 ("[A] [legislative] rule is a mandate by the government with which entities subject to the rule are commanded to comply, often upon threat of sanction.").

93. See Nat'l Mining Ass'n, 758 F.3d at 252 (“[A]gency action that merely interprets a prior statute or regulation, and does not itself purport to impose new obligations or prohibitions or requirements on regulated parties, is an interpretive rule."); Funk, supra note 92, at 1322; Funk, supra note 5, at 659. But see Rakoff, supra note 6, at 167 ("If an agency, without promulgating a nominally-legally-binding regulation, generates a set of detailed guidelines for its inspectors to enforce, it in effect still establishes the law for all those unwilling to pay the expense, or suffer the ill-will of challenging the agency in court.").

94. See Michael Asimow, California Underground Regulations, 44 Admin. L. Rev. 43, 44 (1992); see also Sean Croston, The Petition Is Mightier Than the Sword: Rediscovering an Old Weapon in the Battles over "Regulation Through Guidance", 63 Admin. L. REv. 381, 382-83 (2011) ("[M] eaningful guidance . . . is essentially equivalent to free legal advice for parties confronted with complex legal requirements . . . [and] 
[the] discretion" afforded to it by a statute or other substantive rule. ${ }^{95}$ Very little is required for an agency to adopt a nonlegislative rule, to the point where there may be no notice to or "input" from the public. ${ }^{96}$ The APA requires only that agencies publish nonlegislative rules in the Federal Register upon promulgation. ${ }^{97}$

Nonlegislative rules may carry more legal force and effect than in the past because in practice they have evolved into a mechanism for agencies to more quickly and easily promulgate rules that have direct legal effects on individuals. ${ }^{98}$ The Supreme Court has even indicated a willingness to afford Chevron deference to nonlegislative rules. ${ }^{99}$ In Barnhart v. Walton, ${ }^{100}$ the Court concluded that "the fact that the [a]gency previously reached its interpretation through means less formal than 'notice and comment' rulemaking . . . does not automatically deprive that interpretation of the judicial deference otherwise its due."101 Agencies promulgate vastly more nonlegislative rules than legislative rules, ${ }^{102}$ predominantly because they are incentivized by the relative procedural simplicity and cost advantage associated with the former. ${ }^{103}$ As a result, it is more difficult for

potentially reduces an agency's burden of replying to repeated stakeholder requests for individual interpretations of particular regulations." (footnote omitted) (internal quotation marks omitted)).

95. See Seidenfeld, supra note 9, at 334 .

96. See id. at 342 ("[A]n agency may issue [a nonlegislative rule] with no input even from those with strong interests in it.").

97. See 5 U.S.C. $\$ 552$ (a) (1) (D) (2012).

98. See Gwendolyn McKee, Judicial Review of Agency Guidance Documents: Rethinking the Finality Doctrine, 60 Admin. L. Rev. 371, 377 (2008) (noting nonlegislative rules have become "process-free vehicles for agency declarations of explicit standards and principles that have a real, direct, and potentially devastating impact”); see also U.S. DEP'T OF LABOR, supra note 6; Anthony, supra note 19, at 1047 (noting "practical binding effect" of nonlegislative rules); Croston, supra note 94, at 382-83; Raso, supra note 7, at 789 (stating nonlegislative rules may "have the effect of altering [regulated parties'] conduct").

99. See Barnhart v. Walton, 535 U.S. 212, 221 (2002); United States v. Mead Corp., 533 U.S. 218, 230-31 (2001) ("[A]s significant as notice-and-comment is in pointing to Chevron authority, the want of that procedure here does not decide the case ...."); NationsBank of N.C., N.A. v. Variable Annuity Life Ins. Co., 513 U.S. 251, 260-63 (1995) (affording Chevron deference to Comptroller of Currency's interpretation of National Bank Act).

100. 535 U.S. 212 (2002).

101. Id. at 221 (citation omitted).

102. See Counting Regulations, supra note 7, at 1, 6, 19 (noting "the number of final rules published each year is generally in the range of 2,500-4,500," and that in the most recent year for which data is available, 2014, agencies published 3,554 final rules in the Federal Register, spanning 24,861 pages). In contrast, the 113th Congress, sitting between January 2013 and 2015, enacted just 296 laws and 663 resolutions. See Statistics and Historical Comparison, supra note 7. However, of the 3,554 final rules issued by agencies in 2014, only eighty were considered "major rules," as defined by the Congressional Review Act. See 5 U.S.C. § 804(2) (2012); see also Counting Regulations, supra note 7, at 8 tbl.2.

103. See Croston, supra note 94, at 384; see also Final Bulletin for Agency Good Guidance Practices, 72 Fed. Reg. 3432, 3432 (Jan. 25, 2007) ("Because it is proce- 
Villanova Law Review, Vol. 61, Iss. 5 [2017], Art. 1

the regulated public to challenge nonlegislative rules in the federal courts because agencies can argue either that a nonlegislative rule is not final ${ }^{104}$ or is not ripe for review. ${ }^{105}$ Accordingly, nonlegislative rules that actually have a significant legal impact may, and often do, completely "escape judicial review." 106

APA $\S 553(\mathrm{e})$, the focus of this Article, provides that "[e]ach agency shall give an interested person the right to petition for the issuance, amendment, or repeal of a rule." 107 While this provision states that agencies "shall" receive such petitions, Congress did not enact any uniform standards for the handling of such petitions. ${ }^{108}$ To the contrary, legislative history suggests that individual agencies were expected to prescribe procedural rules governing how to handle petitions. ${ }^{109}$ Few agencies have specific guidelines regarding the submission, receipt, and consideration of $\S 553(\mathrm{e})$ petitions. ${ }^{110}$

The phrase "interested person" has been interpreted broadly, to the point that many agencies have determined that "any person may petition"

durally easier to issue guidance documents, there also may be an incentive for regulators to issue guidance documents in lieu of regulations.").

104. Agency action can be challenged in court only when specifically provided by statute, or when the action is considered "final agency action for which there is no other adequate remedy in a court." See 5 U.S.C. $\$ 704$; see also Nat'l Mining Ass'n v. McCarthy, 758 F.3d 243, 252 (D.C. Cir. 2014) (citing Bennett v. Spear, 520 U.S. 154, 177-78 (1997)) ("An agency action is final only if it is both 'the consummation of the agency's decisionmaking process' and a decision by which 'rights or obligations have been determined' or from which 'legal consequences will flow." ”); Nat'l Ass'n of Home Builders v. Norton, 415 F.3d 8, 13 (D.C. Cir. 2005).

105. See Pub. Citizen, Inc. v. U.S. Nuclear Regulatory Comm'n, 940 F.2d 679, 680 (D.C. Cir. 1991) (determining challenge to U.S. Nuclear Regulatory Commission's policy statement was unripe); see also Croston, supra note 94, at 386.

106. See Anthony, supra note 6, at 1318 (“[F] or practical reasons [nonlegislative rules] may escape judicial review altogether.").

107. 5 U.S.C. $\$ 553($ e). But see California Sea Urchin Comm'n v. Bean, Case No. CV 14-8499-JFW (CWx), 2015 WL 5737899, at *6 n.8 (C.D. Cal. Sept. 18, 2015) (noting "the APA does not provide for partial repeal of a rule").

108. See ACUS Recommendation 86-6, supra note 10, at 1 ("[U]niform specification of agency petition procedures would be undesirable because there are significant differences in the number and nature of petitions received by agencies and in the degree of sophistication of each agency's community of interested persons.").

109. See 1947 AG's Manual, supra note 48, at 38 (stating agencies were expected to "establish[] and publish . . . procedural rules governing the receipt, consideration, and disposition of petitions"); see also 92 Cong. Rec. 5651 (1946) ("Every agency possessing rule-making authority will be required to set up procedures .....").

110. See ACUS Recommendation 86-6, supra note 10 , at 1 ("[T] here are significant differences in the number and nature of petitions received by agencies ...."). However, the Seventh Circuit has held that because "[t]he APA does not detail procedures for petitions made pursuant to $\$ 553(\mathrm{e})$," an agency "does not violate the APA by not having detailed procedures governing petitions." See Wis. Elec. Power Co. v. Costle, 715 F.2d 323, 328 (7th Cir. 1983). 
for the issuance, amendment, or repeal of a rule. ${ }^{111}$ However, courts still require petitioners to establish standing before attempting to challenge final agency action such as a denial of a $\S 553(\mathrm{e})$ petition. ${ }^{112}$ The APA does not define the word "petition," but courts have accepted oral petitions in addition to written requests under $\S 553(\mathrm{e}) .{ }^{113}$

Courts and commentators disagree about whether $\S 553(\mathrm{e})$ 's right to petition extends to informal legislative and nonlegislative rules, or simply to legislative rules. ${ }^{114}$ Disagreement exists about agency obligations in handling petitions, and to what judicial recourse individuals may avail themselves when an agency either denies or unreasonably delays adjudicating a petition. ${ }^{115}$ Even among the courts that have permitted judicial review of an agency's inaction or unreasonable delay in adjudicating a petition, the standards of review used to analyze such challenges are not conclusively established. ${ }^{116}$ Accordingly, the APA's Petition Provision continues to perplex the regulated public, agencies, lawyers, and the courts.

APA sections 701 through 706 describe the availability of judicial review of agency action or inaction, and the procedures applicable to such judicial proceedings. ${ }^{117}$ Section 702 provides the general right of judicial review to any person who has suffered a legal wrong or who was adversely

111. See Jason A. Schwartz \& Richard L. Revesz, Petitions for Rulemaking: Final Report to the Administrative Conference of the United States 11 (Nov. 5, 2014), http:/ / www.acus.gov/sites/default/files/documents/Final\%20Petitions\%20for\% 20Rulemaking\%20Report\%20\%5B11-5-14\%5D.pdf [https://perma.cc/5LYU-YUQK].

112. See, e.g., Brown v. FBI, 793 F. Supp. 2d 368, 375 (D.C. Cir. 2011) (stating APA "will not automatically confer Article III standing" on all petitioners).

113. See, e.g., Am. Horse Prot. Ass'n, Inc. v. Lyng, 812 F.2d 1, 5 (D.C. Cir. 1987) (noting APA does not "specif[y] formalities for a rulemaking petition"); see also Schwartz \& Revesz, supra note 111, at 24 ("The APA does not define 'petition' or provide any details in $\$ 553(\mathrm{e})$ on required content.").

114. Compare Seidenfeld, supra note 9, at 370-71 (“[T] he language and structure of $\S 553$ in its entirety clearly indicates that $\S 553(\mathrm{e})$ applies to [nonlegislative rules] . ..."), with Mendelson, supra note 9, at 439-40 ("Despite some commentators' statements that the language of the APA supplies an obvious right to file such a petition under section 553, the few courts to opine on the issue have flatly and unanimously disagreed, finding that no right to petition an agency to revise or repeal an interpretive rule or policy statement exists under current law." (footnote omitted)).

115. See infra Sections III and IV.

116. See infra Section IV.

117. Section 701, the definitional section for agency review, asserts that the APA's judicial review provisions apply, "except to the extent that[:] (1) statutes preclude judicial review; or (2) agency action is committed to agency discretion by law." See 5 U.S.C. $\$ 701$ (a) (2012). Agency action is committed to agency discretion by law "where "statutes are drawn in such broad terms that in a given case there is no law to apply." "See Citizens to Pres. Overton Park, Inc. v. Volpe, 401 U.S. 402, 410 (1971) (quoting 1945 Senate Judiciary Report, supra note 48, at 26), abrogated sub nom. on other grounds by Citizens to Pres. Overton Park, Inc. v. Brinegar, 494 F.2d 1212 (6th Cir. 1974). 
Villanova Law Review, Vol. 61, Iss. 5 [2017], Art. 1

affected by agency action. ${ }^{118}$ "'Agency action' includes the whole or a part of an agency rule[] [or] order .... [a] denial thereof, or [an agency's] failure to act." ${ }^{19}$ Section 704 limits $\$ 702$ 's broad general right of review to only those agency actions explicitly made reviewable by statute, or "final agency action for which there is no other adequate [judicial] remedy." 120 Accordingly, if a statute does not specifically make an agency action reviewable, the action cannot be subject to judicial review unless it is considered "final." 121 Determining whether an agency action is "final" is often a difficult question. ${ }^{122}$

Section 706 details the scope of review available for final agency actions, requiring courts to "decide all relevant questions of law, interpret constitutional and statutory provisions, and determine the meaning or applicability of the terms of an agency action." 123 A reviewing court "must compel agency action unlawfully withheld or unreasonably delayed [ ] and hold unlawful and set aside [any] agency action [s]" found to be "arbitrary, capricious, an abuse of discretion, or otherwise not in accordance with law."124

\section{The Petition Provision Applies to Legislative and Nonlegislative Rules}

The APA's right to petition applies to legislative and nonlegislative rules alike. Agencies must "give an interested person the right to petition

118. See 5 U.S.C. $\$ 702$ ("A person suffering legal wrong because of agency action, or adversely affected or aggrieved by agency action within the meaning of a relevant statute, is entitled to judicial review thereof."). The APA provides a general waiver of sovereign immunity from such suits.

An action in a court of the United States seeking relief other than money damages and stating a claim that an agency or an officer or employee thereof acted or failed to act in an official capacity or under color of legal authority shall not be dismissed nor relief therein be denied on the ground that it is against the United States or that the United States is an Id. indispensable party.

119. 5 U.S.C. $\$ 551(13)$ (2012).

120. See 5 U.S.C. $\$ 704$.

121. See Lujan v. Nat'l Wildlife Fed'n, 497 U.S. 871, 882 (1990). Moreover, $\S 704$ forbids judicial review of "preliminary, procedural, or intermediate agency action.” See 5 U.S.C. $\$ 704$.

122. See, e.g., Sackett v. EPA, 132 S. Ct. 1367, 1371-72 (2012); Bennett v. Spear, 520 U.S. 154, 178 (1997) (noting that agency action "must not be of a merely tentative or interlocutory nature"); Nat'l Mining Ass'n v. McCarthy, 758 F.3d 243, 252 (D.C. Cir. 2014) ("An agency action is final only if it is both the consummation of the agency's decisionmaking process and a decision by which rights or obligations have been determined or from which legal consequences will flow." (internal quotation marks omitted) (citing Bennett, 520 U.S. at 177-78)).

123. See 5 U.S.C. $\$ 706$.

124. See id.; see also Ass'n of Data Processing Serv. Orgs., Inc. v. Bd. of Governors of the Fed. Reserve Sys., 745 F.2d 677, 683 (D.C. Cir. 1984) (noting "that in their application to the requirement of factual support the substantial evidence test and the arbitrary or capricious test are one and the same"). 
[the agency] for the issuance, amendment, or repeal of a rule." ${ }^{25}$ Some courts have appeared to suggest, and commentators have argued, that $\S 553$ (e) applies only to legislative rules. ${ }^{126}$ However, the Petition Provision's language, structure, context, and legislative history indicate that the right to petition applies to all administrative rules. Accordingly, any interested person is entitled to petition for the issuance, amendment, or repeal of any rule.

Though the issue has been addressed infrequently and in passing, courts and commentators have yet to delve into the question of whether $\S 553$ (e) applies to nonlegislative rules. ${ }^{127}$ Of the scarce scholarly research available regarding this question, the general view, shared by this Article's authors, concludes that $\S 553$ (e) applies to nonlegislative rules. One scholar argues that "[b]ecause guidance documents clearly are rules under the APA," $\$ 553(\mathrm{e})$ must apply to nonlegislative rules. ${ }^{128}$ Other scholars note that "the right to petition extends beyond traditional legislative rules with general policy effects." ${ }^{29}$ However, another scholar indi-

125. See 5 U.S.C. $\$ 553(\mathrm{e})$.

126. See Mendelson, supra note 9, at 439-40 n.227 (citing Nat'l Wrestling Coaches Ass'n v. U.S. Dep't of Educ., 263 F. Supp. 2d 82 (D.D.C. 2003), aff'd on other grounds, 366 F.3d 930 (D.C. Cir. 2004)); Atchison, Topeka \& Sante Fe Ry. Co. v. Peña, 44 F.3d 437 (7th Cir. 1994); United Transp. Union v. Del. \& Hudson Ry., Co., 977 F. Supp. 570 (N.D.N.Y. 1997)).

127. A few courts and scholars have quickly passed over this question, mentioning without specific analysis of the issue that $\$ 553$ (e) either applies to nonlegislative rules or that it does not. See LubBers, supra note 33, at 73; Asimow, supra note 94, at 44 n.5 ("All rules, legislative and nonlegislative, are subject to the right of an interested person to petition . ..."); Michael Asimow, Nonlegislative Rulemaking and Regulatory Reform, 1985 Duke L.J. 381, 424 ("[T] he public can create the [ ] burden under existing law by petitioning . . ...); Royal C. Gardner, Public Participation and Wetlands Regulation, 10 UCLA J. EnvtL. L. \& PoL'y 1, 21 (1991) (noting "petition[ing] the agency to reconsider or repeal its pronouncement" is one method of public redress); William V. Luneburg, Petitioning Federal Agencies for Rulemaking: An Overview of Administrative and Judicial Practice and Some Recommendations for Improvement, 1988 WIS. L. REv. 1, 13-14 ("[T] he APA petition process encompasses not only so-called legislative or substantive rules . . . but also procedural rules, interpretative rules and general statements of policy." (internal quotation marks omitted)); Mendelson, supra note 9, at 439-40 n.227 (and cited cases); Seidenfeld, supra note 9, at 371-72 (stating issue of whether $\S 553$ (e) applies to nonlegislative rules has not been judicially resolved); Schwartz \& Revesz, supra note 111 , at 12 (" $[\mathrm{I}] \mathrm{t}$ seems unlikely that a court would find the APA requires any specific agency official to follow any specific procedure in considering petitions .....").

128. See Seidenfeld, supra note 9 , at 370-71.

129. See Schwartz \& Revesz, supra note 111, at 27; see also LubBers, supra note 33, at 73 (noting nonlegislative rules are "not exempt from section 553's petition provision"); Asimow, supra note 94, at 44 n.5 (citing 5 U.S.C. $\$ 553(\mathrm{e})$ ); Asimow, supra note 127, at 424; Gardner, supra note 127, at 21 ("Although the public may not challenge an agency's statement of policy or interpretative rule for lack of public notice and comment, individuals aggrieved by such rules [may] ... petition the agency to reconsider or repeal its pronouncement."); Luneburg, supra note 127, at 13-14 (citing 1947 AG's MANUAL, supra note 48, at 38) ("[T] he APA peti- 
Villanova Law Review, Vol. 61, Iss. 5 [2017], Art. 1

cated that no right to petition for the issuance, amendment, or repeal of nonlegislative rules exists under current case law. ${ }^{130}$

Case law on the topic is similarly scarce and often conflicting. Some cases opine or observe that $\S 553(\mathrm{e})$ does not apply to nonlegislative rules. ${ }^{131}$ However, the statements in these cases are dicta, omitting any consideration of the text, structure, context, and legislative history of $\S 553(\mathrm{e}) .{ }^{132}$ Notably, the D.C. Circuit has observed in dictum, in line with the Authors' views, that $\S 553$ (e)'s right to petition applies to nonlegislative rules. ${ }^{133}$ The court stated that, even if a nonlegislative rule were reached without notice and comment, "the interests affected would at least have

tion process encompasses not only so-called 'legislative' or 'substantive' rules . . . but also procedural rules, interpretative rules and general statements of policy.”).

130. See Mendelson, supra note 9, at 439-40 n.227 (“[T] he few courts to opine on the issue have ... [found] that no right to petition an agency to revise or repeal an interpretive rule or policy statement exists under current law." (citing Nat'l Wrestling Coaches Ass'n, 263 F. Supp. 2d at 128; Atchison, 44 F.3d at 442; United Transp. Union v. Del. E् Hudson Ry., Co., 977 F. Supp. at 574 n.2)).

131. In Atchison, Topeka E Santa Fe Railway Co. v. Peña, the Seventh Circuit stated that "interested parties do not have the right to petition the agency for review of its interpretive rulings as they do with respect to agency rules." See Atchison, 44 F.3d at 442 (citing 5 U.S.C. $\$ 553(\mathrm{e})$ ). The Atchison court's opinion further stated that the plaintiffs "were not permitted to petition the [agency] for review of its new interpretation; when they did, the [agency] (properly) informed them that it was not required to respond." See id. In Nat'l Wrestling Coaches Ass'n v. Dep't of Educ. (Nat'l Wrestling I), the District Court for the District of Columbia stated that $\S 553(\mathrm{e})$ "by its terms, does not apply to interpretive rules, general statements of policy, or rules of agency organization, procedure or practice unless notice or hearing is required by statute." Nat'l Wrestling I, 263 F. Supp. 2d at 128 (internal quotation marks omitted) (citing 5 U.S.C. $\$ 553(\mathrm{e})$ ). The D.C. Circuit affirmed Nat'l Wrestling I in Nat'l Wrestling Coaches Ass'n v. Dep't of Educ. (Nat'l Wrestling II). See Nat'l Wrestling II, 366 F.3d 930 (D.C. Cir. 2004). Finally, in United Transportation Union v. Delaware $\mathcal{E}$ Hudson Railway Co., the Northern District of New York stated that "interested parties do not have the right to petition the agency for review of its interpretive rulings as they do with respect to agency rules." United Transp. Union, 977 F. Supp. at 574 n.2 (citing 5 U.S.C. $\$ 553(\mathrm{e})$ ).

132. In Atchison, the court did not need to reach the issue of whether $\S 553(\mathrm{e})$ applied to nonlegislative rules because it invalidated the interpretive rule on its merits, and the court's brief discussion regarding $\$ 553(\mathrm{e})$ was only a small part of its analysis concerning how much deference to afford interpretive rules. See Atchison, 44 F.3d at 442. With regard to United Transportation Union, the court was not even faced with a $\S 553$ (e) petition to enact, amend, or repeal a nonlegislative rule, so any such discussion was dictum. See United Transp. Union, 977 F. Supp. at 574 n.2 (discussing judicial deference afforded agencies' interpretive rules). Finally, in Nat'l Wrestling II, the D.C. Circuit affirmed Nat'l Wrestling I on other grounds, and while holding that the documents at issue in Nat'l Wrestling I did not even constitute a valid $\$ 553(\mathrm{e})$ petition, the D.C. Circuit stated that it was "[1] eaving aside any difficulties as to whether the [rule at issue] is the type of policy subject to the APA's petition requirements." See Nat'l Wrestling II, 366 F.3d at 948; see also Seidenfeld, supra note 9, at 372 (" $[\mathrm{N}]$ one of these opinions considered the specific language, structure, or legislative history of the APA's treatment of guidance documents.").

133. See Guardian Fed. Savs. \& Loan Ass'n v. Fed. Savs. \& Loan Ins. Corp., 589 F.2d 658, 668 (D.C. Cir. 1978) ("When there has been no procedure for comment in the first instance, a petition to modify may serve an appropriate objective."). 
the opportunity to invoke subsection 553(e) of the APA to petition for a modification, an opportunity in effect to assure some agency consideration of comments."134

A textual reading of the Petition Provision supports the notion that it applies to nonlegislative rules. Section 553(e), by its terms, applies to "rule[s]."135 A rule is "the whole or a part of an agency statement of general or particular applicability and future effect designed to implement, interpret, or prescribe law or policy or describing the organization, procedure, or practice requirements of an agency." ${ }^{136}$ Nonlegislative rules squarely fit within this definition. A nonlegislative rule can certainly apply either generally or specifically, and such rules have future effect because "they provide guidance as to what the agency's views will be." 137 They either interpret law or prescribe policy in that they tell "the world how an agency construes a particular provision in an existing statute." 138 Finally, while not carrying the force of law, "valid interpretive rules are binding to the extent that they "merely interpret' already existing legal duties."139 Accordingly, the term "rule" in the APA refers to both legislative and nonlegislative rules. ${ }^{140}$

While legislative history is silent on the issue, the Attorney General's Manual supports the idea that $§ 553(\mathrm{e})$ 's Petition Provision applies to nonlegislative rules. It states that the Petition Provision "applies not only to substantive rules but also to interpretations and statements of general policy, and to organizational and procedural rules."141 The D.C. Circuit has noted that, except where inconsistent with the Senate Judiciary Committee's Report, the Attorney General's Manual is "entitled to some defer-

134. See id. at 668; see also Seidenfeld, supra note 9, at 372 n.220 (citing Guardian Fed. Savs. E Loan Ass'n, 589 F.2d at 668).

135. See 5 U.S.C. $\$ 553($ e) (2012).

136. Id. $\S 551(4)$.

137. See Funk, supra note 6, at 1323; see also Hoctor v. U.S. Dep't of Agric., 82 F.3d 165, 167 (7th Cir. 1996) ("Every governmental agency that enforces a less than crystalline statute must interpret the statute," and a nonlegislative rule can announce "the interpretation [of the statute] in advance of enforcement."); see also Asimow, supra note 94, at 44 (stating nonlegislative rules explain "to the public and to agency staff how the agency believes law should be interpreted, discretion should be exercised, or agency functions carried out"); Funk, supra note 92, at 1322 ("Nonlegislative rules can encompass a wide variety of agency pronouncements."); Morrison, supra note 18, at 89.

138. See Morrison, supra note 18 , at 89.

139. See Gersen, supra note 71, at 1711.

140. See Funk, supra note 92, at 1322 ("[A] 'rule' under the APA includes both 'interpretative rules' and 'general statements of policy' . . ." (citing 5 U.S.C. $\S 551(4)(2012))$.

141. See 1947 AG's Manual, supra note 48, at 38. But see Natural Res. Def. Council, Inc. v. SEC, 606 F.2d 1031, 1043 n.14 (D.C. Cir. 1979) (noting "[t]he Attorney General's gloss on the APA is entitled to some deference because of the role played by the Department of Justice in drafting the legislation [,]" except "to the extent that it is inconsistent with the Senate Committee Report"). 
Villanova Law Review, Vol. 61, Iss. 5 [2017], Art. 1

ence" on the topic. ${ }^{142}$ The Senate Report also indicates that $\S 553(\mathrm{e})$ applies to nonlegislative rules, stating that "[w] here public rule-making procedures are dispensed with, the provisions of subsections (c) and (d) [currently $\S 553(\mathrm{e})]$ of this section would nevertheless apply." 143

Section 553's structure also supports the notion that the Petition Provision applies to nonlegislative rules, ${ }^{144}$ upon incorporating expressio unius est exclusio alterius. ${ }^{145}$ Had Congress intended to exempt nonlegislative rules from the Petition Provision, it would have either included a specific exemption in $\S 553$ (e) similar to those in $\S(\mathrm{b})$ and $\S(\mathrm{d})$, or it would have included the exemption in $\S 553(\mathrm{a})$, which applies to the remainder of $\S 553$. $^{146}$ Section 553(a) exempts certain matters and affairs from all remaining subsections of $\S 553 .{ }^{147}$ Section 553(b) outlines the APA's notice requirements for proposed rulemaking, mandating publication in the Federal Register, but explicitly exempts nonlegislative rules. ${ }^{148}$ Section 553(c) states that "[a]fter notice required by this section, the agency shall give interested persons an opportunity to participate in the rule making," 149 but because $\S 553$ (b) exempts nonlegislative rules from its notice requirements, $\S 553$ (c)'s provisions are similarly understood not to apply to nonlegislative rules. ${ }^{150}$ Section $553(\mathrm{~d})$ requires publication of substantive rules, but also specifically exempts nonlegislative rules. ${ }^{151}$ Conversely, $\S 553(\mathrm{e})$ contains no exemptions for nonlegislative rules. ${ }^{152}$ Thus, $\S 553$ (e) was not intended to exclude nonlegislative rules.

142. See Natural Res. Def. Council, 606 F.2d at 1043 n.14; see also Norton v. S. Utah Wilderness Alliance, 542 U.S. 55, 63-64 (2004) (citation omitted) (indicating Court has "often found [Attorney General's Manual] persuasive" (citations omitted)).

143. See 1945 Senate Judiciary Report, supra note 48, at 14.

144. See Seidenfeld, supra note 9, at 371 n.212 (outlining statutory construction argument briefly).

145. See Chevron U.S.A. Inc. v. Echazabal, 536 U.S. 73, 80 (2002).

146. See Seidenfeld, supra note 9, at 371 n.212 ("Read in isolation, it might be possible for one to interpret the exception in $\S 553(\mathrm{~b})$ as intending to exempt guidance documents from all of $\$ 553$. But, the second explicit exemption in subsection (d) and the fact that subsection (a) lays out the exemptions to the entire section deprive this interpretation of any plausibility.").

147. See 5 U.S.C. $\$ \$ 55$ (a) (1)-(2) (2012) (exempting "military or foreign affairs function [s]" and "matter[s] relating to agency management or personnel or to public property, loans, grants, benefits, or contracts").

148. See id. $\$ 553(\mathrm{~b})$.

149. Id. $\S 553(\mathrm{c})$.

150. See, e.g., 1947 AG's Mandal, supra note 48, at 30 (noting subsections (a) and (c) "must be read together because the procedural requirements of subsection [(c)] apply only where notice is required by subsection (a)"); Seidenfeld, supra note 9, at $371 \mathrm{n} .212$ ("[T] here is a consensus that the comment requirement in subsection (c) does not apply to such [guidance] documents."). Note that subsections 4(a) and 4(b) of the public law referred to in the Attorney General's Manual corresponds to subsections 553(b) and 553(c) of the APA.

151. See 5 U.S.C. $\$ 553(\mathrm{~d})$.

152. See id. $\$ 553(\mathrm{e})$ (containing no exemptions). 


\section{Agencies Must Adjudicate Every Petition for Rulemaking}

The APA mandates that administrative agencies must consider and respond to every petition under $\$ 553(\mathrm{e})$. An individual's right to petition and an administrative agency's duties with respect to that petition are governed by the First Amendment, the APA, and any applicable authorizing statute for a particular agency. ${ }^{153}$ The First Amendment provides individuals with the irreducible right to submit petitions to administrative agencies but does not confer any corresponding duty upon agencies to consider or "respond to" any petitions. ${ }^{154}$ The First Amendment also provided the inspiration for the APA's Petition Provision, ${ }^{155}$ though Congress did not believe that the First Amendment sufficiently protected the right to petition. Accordingly, Congress provided individuals with greater rights and protections in the APA, and conferred additional duties upon agencies. $^{156}$

\section{A. The First Amendment Guarantees the Right to Petition Agencies for a Redress of Grievances}

The First Amendment provides, in part, that "Congress shall make no law . . . abridging . . . the right of the people . . . to petition the government for a redress of grievances." ${ }^{157}$ Rather than as creating the right to petition for a redress of grievances, the First Amendment is viewed as prohibiting the government from "interfering" with an individual's inher-

153. See Schwartz \& Revesz, supra note 111, at 7-11 (summarizing bases for right to petition); see also U.S. ConsT., amend. I ("Congress shall make no law . . . abridging ... the right of the people ... to petition the [g] overnment for a redress of grievances."); 5 U.S.C. \$ 553(e) ("Each agency shall give an interested person the right to petition ....").

154. See Minn. State Bd. for Cmty. Colls. v. Knight, 465 U.S. 271, 272 (1984) ("Nothing in the First Amendment or in this Court's case law interpreting it suggests that the rights to speak, associate, and petition require government policymakers to listen or respond to communications of members of the public on public issues.”); Smith v. Ark. State Highway Emps., Local 1315, 441 U.S. 463, 465 (1979) ("[T] he First Amendment does not impose any affirmative obligation on the government to listen [or] to respond ....").

155. See S. Doc. No. 79-248, at 21 (1946) [hereinafter 1946 Senate DocuMENT] ("Even Congress, under the Bill of Rights, is required to accord the right of petition to any citizen."); 92 Cong. REc. 5651 (1946) ("The right of petition is written into the Constitution itself."); see also Luneburg, supra note 127, at 10 ("Such an interpretation of section 553(e) finds support in legislative history explaining that the $[\mathrm{F}]$ irst $[\mathrm{A}]$ mendment's right to petition provided the inspiration for section 553(e).”).

156. See 1946 Senate Document, supra note 155, at 21; see also Luneburg, supra note 127, at 6 ("Congress has seen fit to go beyond the [F]irst [A]mendment's strictures .....”).

157. See U.S. Const., amend. I; We the People Found., Inc. v. United States, 485 F.3d 140, 141 (D.C. Cir. 2007) (quoting U.S. Const., amend. I). 
Villanova Law Review, Vol. 61, Iss. 5 [2017], Art. 1

ent right to petition. ${ }^{158}$ The First Amendment right to petition serves three main purposes: (1) "protect[ing] individuals and minority groups by giving extraordinary power to even a single individual" with the power to effect change; (2) combating "attenuated representation"; and (3) providing a mechanism for the people to "inform [those in government] about local conditions" and "needs." 159

The Supreme Court has concluded that the right to petition is not limited solely to the "redress of grievances," but "more broadly" for anything connected with the powers or duties of the government. ${ }^{160}$ Accordingly, the Court has extended the right to petition to all departments of the federal government, including administrative agencies. ${ }^{161}$ However, the constitutional right to petition an administrative agency for rulemaking does not carry any guarantee of agency consideration or response. ${ }^{162}$ The Supreme Court has denied any corresponding right at least twice, ${ }^{163}$ as has the D.C. Circuit. ${ }^{164}$ One scholar opined that the First Amendment guarantees "little more than the right to make a clamor." 165

D.C. Circuit Judge Judith Rogers's concurring opinion in We the People Foundation, Inc. v. United States ${ }^{166}$ cites seven law review articles for the

158. See Schwartz \& Revesz, supra note 111, at 7 (“[T] he Constitution implies that the public already and inherently possesses the right [to petition], and so it merely prohibits the government from interfering with petitions.").

159. See id. at 7-8 (discussing Akhil Reed Amar, The Bill of Rights As a Constitution, 100 YALE L.J. 1131 (1991)); see also Amar, supra at 1156.

160. See United States v. Cruikshank, 92 U.S. 542, 551 (1875) (referring to right to petition Congress as "an attribute of national citizenship"); see also Schwartz \& Revesz, supra note 111, at 8 (citing E. R.R. Presidents Conference v. Noerr Motor Freight, Inc., 365 U.S. 127, 138 (1961)) ("The Supreme Court has interpreted the right as not literally confined to demands for "redress of grievances,' but as more broadly encompassing requests for the exercise of government power.").

161. See Cal. Motor Transp. Co. v. Trucking Unlimited, 404 U.S. 508, 510 (1972) ("The same philosophy governs the approach of citizens or groups of them to administrative agencies (which are both creatures of the legislature, and arms of the executive) and to courts, the third branch of Government."); see also 92 Cong. Rec. 5651 (1946) (stating APA "confirms [the constitutional right to petition] where Congress has delegated legislative powers to administrative agencies").

162. See Schwartz \& Revesz, supra note 111, at 8. Schwartz and Revesz identify case law discussing the lack of a guaranteed governmental response. See id.; see also Minn. State Bd. for Cmty. Colls. v. Knight, 465 U.S. 271, 285 (1984); Smith v. Ark. State Emps., Local 1315, 441 U.S. 463, 465 (1979); We the People Found., Inc. v. United States, 485 F.3d 140, 143 (D.C. Cir. 2007) ("Plaintiffs contend that they have a right under the First Amendment to receive a government response to or official consideration of a petition for a redress of grievances. We disagree.").

163. See Minn. State Bd. for Cmty. Colls., 465 U.S. at 285; see also Ark. State Emps., Local 1315, 441 U.S. at 465 ("[T] he First Amendment does not impose any affirmative obligation on the government to listen, to respond . . ..").

164. Am. Bus Ass'n v. Rogoff, 649 F.3d 734, 739-40 (D.C. Cir. 2011) (quoting Minn. State Bd. for Cmty. Colls., 465 U.S. at 285); We the People Found., Inc., 485 F.3d at 143 .

165. See Luneburg, supra note 127, at 6.

166. 485 F.3d 140 (D.C. Cir. 2007). 
proposition that at the time of the First Amendment's passage, it was understood to require a governmental response. ${ }^{167}$ Judge Rogers suggests that an "interesting question" would arise should the Supreme Court again consider the question. ${ }^{168}$ Contemporary case law holds that the First Amendment right to petition provides the irreducible minimum of protections afforded, while the APA expands upon these basic rights.

\section{B. The APA's Expansion of the First Amendment's Right to Petition}

The APA's Petition Provision was modeled after the First Amendment's guarantee. ${ }^{169}$ While it may appear that $\$ 553(\mathrm{e})$ simply mirrors the right protected by the First Amendment, ${ }^{170}$ its text and legislative history strongly suggest that $\S 553(\mathrm{e})$ was intended to confer on individuals a right to agency consideration and response to all qualifying petitions, and therefore confer on agencies a corresponding duty to consider and respond to all petitions.

While the First Amendment presumes an inherent right to petition the government, subsection (e) requires that agencies "give" individuals a right to petition, suggesting that Congress intended to confer a greater right. ${ }^{171}$ The Seventh Circuit noted that the "minimal procedural requirement" of a response to a petition "may be implicit in the APA's structure" in Wisconsin Electric Power Co. v. Costle. ${ }^{172}$ The court observed that absent a corresponding right to receive a response, the right given by $\$ 553(\mathrm{e})$ could become meaningless. ${ }^{173}$ "A statutory outcome is absurd if it defies rationality," and courts are keen to avoid giving statutes a reading that

167. See We the People Found., Inc., 485 F.3d at 147-49 (Rogers,J., concurring) (citing multiple scholars who have argued for this interpretation of First Amendment); see also, e.g., Amar, supra note 159, at 1156 ("[T] he right to petition implied a corresponding congressional duty to respond .....”); James E. Pfander, Sovereign Immunity and the Right to Petition: Toward a First Amendment Right to Pursue Judicial Claims Against the Government, 91 Nw. U.L. Rev. 899, 905 n.22 (1997) ("[M]ost scholars agree that the right to petition includes a right to some sort of considered response.”); Julie M. Spanbauer, The First Amendment Right to Petition Government for a Redress of Grievances: Cut from a Different Cloth, 21 Hastings Const. L.Q. 15, 17, 33 (1993) ("Inherent in the right to petition was a corresponding right to a response.").

168. See We the People Found., Inc., 485 F.3d at 149 (Rogers, J., concurring).

169. See 1946 Senate Document, supra note 155, at 21 ("Even Congress, under the Bill of Rights, is required to accord the right of petition to any citizen."); 92 Cong. Rec. 5651 (1946) ("The right of petition is written into the Constitution itself."); see also 5 U.S.C. $\$ 553(\mathrm{e})$ (2012) (codifying right to petition).

170. Compare U.S. Const. amend. I, with 5 U.S.C. $\$ 553(\mathrm{e})$; see also Schwartz \& Revesz, supra note 111, at 9.

171. See Schwartz \& Revesz, supra note 111, at 9 (stating Section 553(e) "tells agencies they must 'give' the public the right, perhaps revealing the creation of some new aspect of the right").

172. See Wis. Elec. Power Co. v. Costle, 715 F.2d 323, 328 (7th Cir. 1983).

173. See id. ("This minimal procedural requirement may be implicit in the APA's structure if our review is to be meaningful."). 
would lead to "absurd results." 174 Effectively decimating the $§ 553(\mathrm{e})$ right to petition by permitting agencies to ignore petitions would create such an irrational and absurd result. Accordingly, §553(e) was likely intended to provide greater rights than those already provided by the First Amendment-the right to agency consideration of, and response to, all $\S 553(\mathrm{e})$ petitions.

Legislative history provides a strong indication that Congress intended for agencies to consider and respond to each petition. A 1945 Report from the Senate Committee on the Judiciary stated that " $[w]$ here such petitions are made, the agency must fully and promptly consider them, [and] take such action as may be required." 175 The Senate Report then gave agencies three options: "grant the petition, undertake public rule making proceedings ... or deny the petition."176 A 1946 Report from the House Committee on the Judiciary echoed this view, stating that " $[w]$ here such petitions are made, the agency must fully and promptly consider them . . .."177 Moreover, proceedings in the House of Representatives and the Senate suggested that agencies could not simply receive petitions in a "pro forma manner," 178 and sought to require that each agency establish procedures for the consideration and adjudication of petitions. ${ }^{179}$

\section{The Petition Provision's Context in the APA Suggests That Agencies Are Required to Consider and Respond to Every Petition}

The context of the APA's Petition Provision suggests that an agency must consider and respond to every petition it receives. Two subsections of $\S 555$ highlight this agency duty. Section 555 (b) states that "[w]ith due regard for the convenience and necessity of the parties or their represent-

174. See Landstar Express Am., Inc. v. Fed. Mar. Comm'n, 569 F.3d 493, 498 (D.C. Cir. 2009); Robbins v. Chronister, 435 F.3d 1238, 1241 (10th Cir. 2006) ("When statutory language reasonably admits of alternative constructions, there is nothing remarkable about resolving the textual ambiguity against the alternative meaning that produces a result the framers are highly unlikely to have intended. We choose the reasonable result over the 'absurd' one."); see also John F. Manning, The Absurdity Doctrine, 116 Harv. L. Rev. 2387, 2389 (2003) ("Over the years, in countless decisions-many of them well known-the [Supreme Court] has adjusted unambiguous statutory commands to avoid absurd results.").

175. See 1945 Senate Judiciary Report, supra note 48, at 201. The Report further states that Petition Provision "requires the reception and consideration of petitions." See id. at 226; see also WWHT, Inc. v. FCC, 656 F.2d 807, 813 (D.C. Cir. 1981) (noting legislative history "makes it plain that an agency must receive and respond to petitions for rulemaking").

176. See 1945 Senate Judiciary Report, supra note 48, at 201.

177. See H.R. Rep. No. 79-1980, at 260 (1946).

178. See 92 Cong. Rec. 5651 (1946).

179. See id.; see also 1947 AG's Manual, supra note 48, at 38 ("Every agency with rule making powers . . . should establish, and publish . . . procedural rules governing the receipt, consideration and disposition of petitions filed pursuant to section $[553(\mathrm{e})] . ")$. 
atives and within a reasonable time, each agency shall proceed to conclude a matter presented to it." 180 Section 555(e) states that "[p]rompt notice shall be given of the denial in whole or in part of a written application, petition, or other request." 181 Taken together, these statements mandate that agencies must "conclude" all matters presented to them, including petitions, "within a reasonable time," and that if the agency decides not to issue, amend, or repeal a rule, it must notify the petitioner promptly of that denial. In the petition context, the language of $\S 555$ (b) clarifies that agencies remain free to arrange their agendas and priorities as they see fit, so long as a petition is not ignored for an unreasonable time. ${ }^{182}$ The remainder of $\S 555(\mathrm{~b})$ requires an agency to "conclude" a petition, either by granting or denying the $\$ 553(\mathrm{e})$ petition. ${ }^{183}$ Accordingly, within a reasonable time, an agency must grant or deny every petition under $\S 553(\mathrm{e})$.

If an agency grants a petition under $\S 553$ (e) by issuing, amending, or repealing a rule, the petitioner would receive at least constructive notice through publication in the Federal Register (either thirty days before promulgating the legislative rule or upon issuance for a nonlegislative rule). ${ }^{184}$ If the agency were to deny a petition, in whole or in part, $\S 555$ (e) explicitly requires that the agency "prompt[ly]" notify the petitioner. ${ }^{185}$ Therefore, if the agency grants or denies a $\S 553(\mathrm{e})$ petition, the petitioner will receive notice. Accordingly, $§ 555(\mathrm{~b})$ and $\S 555(\mathrm{e})$, in conjunction, require that agencies, within a reasonable time, consider and respond to every petition for the issuance, amendment, or repeal of a rule.

\section{Contemporary Case Law Suggests a Requirement to Adjudicate Each Petition}

While the Supreme Court has not ruled on the issue, various courts have held that agencies must, at a minimum, respond to every petition for rulemaking. The D.C. Circuit stated that the APA's legislative history "makes it plain that an agency must receive and respond to petitions for rulemaking." 186 A Ninth Circuit panel observed that an agency responded to a nonlegislative rulemaking petition "as it must under the

180. See 5 U.S.C. $§ 555$ (b) (2012).

181. Id. $\S 555(\mathrm{e})$.

182. See id. $\$ 555$ (b); see also Schwartz \& Revesz, supra note 111, at 13 ("Courts have repeatedly cited $\S 555$ (b) . . . to apply a standard of reasonableness to review delayed responses on petitions for rulemaking."). A discussion of what courts have considered an unreasonable amount of time is addressed below in Section IV.

183. See Luneburg, supra note 127, at 9 ("[S]ection 555 (b) requires final disposition by grant or denial.").

184. See 5 U.S.C. $\$ 553(\mathrm{~d})$.

185. See id. $\$ 555(\mathrm{e})$.

186. See WWHT, Inc. v. FCC, 656 F.2d 807, 813 (D.C. Cir. 1981). 
Villanova Law Review, Vol. 61, Iss. 5 [2017], Art. 1

[APA]."187 District judges in both the District of the District of Columbia and the Southern District of New York have held that agencies are "required to at least definitively respond to ... petition[s] - that is, to either deny or grant the petition[s]." 188 Moreover, it appears that the majority of commentators to opine on the issue believe that the APA's Petition Provision requires agencies to consider and respond to each petition. ${ }^{189}$

\section{Adjudicative Inaction and Unreasonable Delay of a Rulemaking Petition Are Subject to Judicial Review}

Agency inaction or unreasonable delay in adjudicating a $§ 553(\mathrm{e})$ petition is explicitly justiciable, and courts should uniformly employ the D.C. Circuit's TRAC test in this analysis. Upon the receipt of a rulemaking petition, an agency will either grant it, delay or fail to adjudicate it, or deny it. ${ }^{190}$ If the agency grants the petition, the petitioner will likely not seek to litigate the issue, though an adversely affected third party might. ${ }^{191}$ In each other scenario, however, an individual's rights are not conclusively established under current law. ${ }^{192}$ If an agency fails to adjudicate or delays unreasonably in adjudicating a petition, courts uniformly accept that the petitioner has the right to review, but there is no uniform standard of review. If an agency denies a petition, the petitioner likely lacks a right of review altogether. Such a lack of clear rights could cause the right to peti-

187. See Horne v. U.S. Dep't of Agric., 494 F. App'x 774, 776-77 (9th Cir. 2012) (concluding U.S. Department of Agriculture failed to provide sufficient explanation "of its reasons for denying [ ] rulemaking petition").

188. See Families for Freedom v. Napolitano, 628 F. Supp. 2d 535, 540 (S.D.N.Y. 2009); see also Nat'l Parks Conservation Ass'n v. Dep't of Interior, 794 F. Supp. 2d 39, 44 (D.D.C. 2011) (quoting Families for Freedom, 628 F. Supp. 2d at 540).

189. See Pfander, supra note 167 , at 905 n.22 (stating that "[a]s a matter of history, most scholars agree that the right to petition includes a right to some sort of considered response" and listing number of scholars who have argued as such); see also Richard J. Pierce, Jr., Administrative Law Treatise $\$ 6.10$ (4th ed. 2002) ("At a minimum, the right to petition for rulemaking entitles a petitioning party to a response to the merits of the petition.").

190. These agency actions are not necessarily mutually exclusive. For example, an agency may unreasonably delay and then grant or deny the petition.

191. Disagreement exists as to exactly what it means to "grant" a petition. The majority view is that a petition is granted when the agency issues an NPRM, while the minority view is that a grant "occurs only with rule adoption." See Luneburg, supra note 127, at 13. This Article rejects the majority view because it solely contemplates the granting of a legislative rule. This Article specifically argues that an agency could potentially grant a petition to enact a nonlegislative rule, which would not require an NPRM under the APA. Further, "courts can review both the termination of an ongoing rulemaking and delay in finalizing a rulemaking that was intended to respond to a petition .... [and] may treat the cessation of a rulemaking with more scrutiny than a straight denial of a petition." See Schwartz \& Revesz, supra note 111, at 26 (footnote omitted).

192. See Bull, supra note 11, at 304 ("The case law addressing appeals of agency dispositions of petitions for rulemaking has been somewhat vague concerning the standard of review that courts will apply."). 
tion to become meaningless. ${ }^{193}$ Courts should uniformly apply the D.C. Circuit's TRAC test to resolve challenges of agency delay and inaction, and also acknowledge that denials of rulemaking petitions are not per se foreclosed from substantive review. ${ }^{194}$

As explained above in Section III.C, $\S 555$ (b) and $\S 555(\mathrm{e})$, in conjunction, require that an agency adjudicate and respond to every petition within a reasonable time. ${ }^{195}$ Section 706 gives this statutory right teeth, providing that district courts "shall [ ] compel agency action unlawfully withheld or unreasonably delayed." 196 Accordingly, an agency's inaction or unreasonable delay in adjudicating a $§ 553$ (e) petition is explicitly justiciable under the APA.

Courts uniformly acknowledge that they have the power to compel an agency to adjudicate a petition for rulemaking. ${ }^{197}$ In particular, the D.C. Circuit consistently signals its willingness to compel an agency to adjudicate a petition after an unreasonable delay, in an effort to correct "transparent violations of a clear duty to act." 198 Commentators note that in many cases of agency inaction, courts are hesitant to second-guess agency

193. See Wis. Elec. Power Co. v. Costle, 715 F.2d 323, 328 (7th Cir. 1983).

194. The task of establishing a comprehensive limiting principle for such review is not in the scope of this Article's inquiry.

195. See supra notes 181-86 and accompanying text.

196. See 5 U.S.C. $§ 706(1)$ (2012) (emphasis added); In re. Natural Res. Def. Council, 645 F.3d 400, 406 (D.C. Cir. 2011) ("[I]n cases brought under APA $\S 706(1)$. . . jurisdiction lies in the district court." (citations omitted) (citing Mashpee Wampanoag Tribal Council, Inc. v. Norton, 336 F.3d 1094, 1099-100 (D.C. Cir. 2003))); Cmty. Nutrition Inst. v. Novitch, 583 F. Supp. 294 (D.D.C. 1984)). But see Norton v. S. Utah Wilderness Alliance, 542 U.S. 55, 64 (2004) (concluding judicial review under APA $\S 706(1)$ "can proceed only where a plaintiff asserts that an agency failed to take a discrete agency action that it is required to take" as opposed to broad programmatic attack).

197. See, e.g., In re Pesticide Action Network N. Am., 532 F. App'x 649, 650 (9th Cir. 2013); In re Am. Rivers \& Idaho Rivers United, 372 F.3d 413, 418 (D.C. Cir. 2004) ("[W]e will interfere with the normal progression of agency proceedings to correct 'transparent violations of a clear duty to act' . . ." (quoting In re Bluewater Network, 234 F.3d 1305, 1315 (D.C. Cir. 2000))); Pub. Citizen Health Research Grp. v. Chao, 314 F.3d 143 (3d Cir. 2002) (“[W]e hold that OSHA's delay in promulgating a [rule] has exceeded the bounds of reasonableness. We therefore grant [petitioner's] petition to compel [the agency] to proceed expeditiously with its . . . rulemaking."); Towns of Wellesley, Concord, \& Norwood, Mass. v. FERC, 829 F.2d 275, 277 (1st Cir. 1987) ("[W]e find that the timing of the FERC's actions in fashioning a final order is not so 'egregious' as to warrant mandamus."); Nat'l Parks Conservation Ass'n v. Dep't of Interior, 794 F. Supp. 2d 39, 44 (D.D.C. 2011); Families for Freedom v. Napolitano, 628 F. Supp. 2d 535, 540 (S.D.N.Y. 2009); see also Morrison, supra note 18, at 96 (“[C] ourts uniformly recognize that at some point, they have the power to require agencies to reach a final decision on a request for rulemaking ...."). Morrison notes, however, that courts "have shown a reluctance to do so except in extreme cases." See id.

198. See In re Am. Rivers, 372 F.3d at 418 (quoting In re Bluewater Network, 234 F.3d at 1315) (noting that " $[\mathrm{a}] \mathrm{n}$ administrative agency's unreasonable delay presents such a circumstance because it signals the 'breakdown of regulatory processes'” (citing Cutler v. Hayes, 818 F.2d 879, 897 n.156 (D.C. Cir. 1987))). 
Villanova Law Review, Vol. 61, Iss. 5 [2017], Art. 1

priorities, ${ }^{199}$ yet judicial review remains an available remedy when agencies fail to act or delay unreasonably in adjudicating a petition.

The APA is silent as to the standard of review a court should employ when deciding claims of agency inaction or delay. ${ }^{200}$ The APA uses the terms "reasonable time" and "unreasonably delayed," but fails to define these terms. ${ }^{201}$ Similarly, the Supreme Court has yet to define these terms or declare a standard of review that should be employed when reviewing agency inaction or delay. ${ }^{202}$ In the circuit courts, however, the most commonly used test is the "TRAC test," first set out by the D.C. Circuit in Telecommunications Research and Action Center v. FCC. ${ }^{203}$

199. See Shapiro \& Murphy, supra note 16, at 27 ("[J] udges have been reluctant to second-guess the lack of a response, instead deferring to agency agendasetting.").

200. See generally APA, Pub. L. 79-404, 60 Stat. 237 (1946).

201. See 5 U.S.C. $\$ \S 555(\mathrm{~b}), 706(1)$; see also LubBERs, supra note 33, at 44 ("[T] he APA's definitional structure is largely circular . . ..").

202. See Michael D. Sant'Ambrogio, Agency Delays: How a Principal-Agent Approach Can Inform Judicial and Executive Branch Review of Agency Foot-Dragging, 79 Geo. Wash. L. Rev. 1381, 1411 (2011) ("The Supreme Court has never addressed how a court should assess agency delay ....").

203. 750 F.2d 70 (D.C. Cir. 1984). The analysis set forth in Telecomms. Research E Action Center v. FCC (TRAC) has since been followed by the First Circuit in Towns of Wellesley, Concord, E Norwood, Mass. v. FERC, 829 F.2d 275, 277 (1st Cir. 1987); the Fourth Circuit in In re City of Va. Beach, 42 F.3d 881, 885 (4th Cir. 1994); the Fifth Circuit in Nat'l Grain E' Feed Ass'n Inc. v. OSHA, 903 F.2d 308, 310 (5th Cir. 1990); the Ninth Circuit in Brower v. Evans, 257 F.3d 1058, 1068-69 (9th Cir. 2001); and the Tenth Circuit in Forest Guardians v. Babbitt, 164 F.3d 1261, 1272-73 (10th Cir. 1998). While some circuit courts do not employ the TRAC Test, "[n] o court has rejected TRAC's reasoning." See Schwartz \& Revesz, supra note 111, at 14 n.62. The Third Circuit uses a four-part test that looks to the following factors:

First, the court should ascertain the length of time that has elapsed since the agency came under a duty to act. Second, the reasonableness of the delay should be judged in the context of the statute authorizing the agency's action. Third, the court should assess the consequences of the agency's delay. Fourth, the court should consider any plea of administrative error, administrative inconvenience, practical difficulty in carrying out a legislative mandate, or need to prioritize in the face of limited resources.

Oil, Chem. \& Atomic Workers Union v. OSHA, 145 F.3d 120, 123 (3d Cir. 1998) (internal quotation marks omitted). The U.S. District Court for the Eastern District of Pennsylvania has explicitly held that, because it is bound by Third Circuit precedent, it would employ the OCAWU test instead of the D.C. Circuit's TRAC test. See Karimushan v. Chertoff, Civil Action No. 07-2995, 2008 U.S. Dist. LEXIS 47167, at *7-8 n.4 (E.D. Pa. June 13, 2008). Additionally, the Second Circuit has never cited TRAC or used it in an agency delay decision, but has rather looked to "the source of delay," analyzing "the complexity of the investigation as well as the extent to which the defendant participated in delaying the proceeding." See Reddy v. Commodity Futures Trading Comm'n, 191 F.3d 109, 120 (2d Cir. 1999) (citing Pub. Citizen Health Research Grp., 740 F.2d at 35). However, district courts within the Second Circuit have, in fact, used the TRAC Test when analyzing claims of agency delay. See, e.g., Families for Freedom v. Napolitano, 628 F. Supp. 2d 535, 540-41 (S.D.N.Y. 2009); Tummino v. Von Eschenbach, 427 F. Supp. 2d 212, 231-32 (E.D.N.Y. 2006); Natural Res. Def. Council, Inc. v. Fox, 93 F. Supp. 2d 531, 
In $T R A C$, the D.C. Circuit noted that while it had decided several unreasonable delay cases, it had not selected one particular test to reach those conclusions. ${ }^{204}$ The court realized however, that these cases formed "the hexagonal contours of a standard." 205 While acknowledging that the standard "is hardly ironclad [ ] and sometimes suffers from vagueness," the TRAC court opined that it would provide "useful guidance" for courts reviewing agency inaction or delay. ${ }^{206}$ In assessing claims of agency delay, the D.C. Circuit instructed courts to look to six factors:

(1) the time agencies take to make decisions must be governed by a rule of reason; (2) where Congress has provided a timetable or other indication of the speed with which it expects the agency to proceed in the enabling statute, that statutory scheme may supply content for this rule of reason; (3) delays that might be reasonable in the sphere of economic regulation are less tolerable when human health and welfare are at stake; (4) the court should consider the effect of expediting delayed action on agency activities of a higher or competing priority; (5) the court should also take into account the nature and extent of the interests prejudiced by delay; and (6) the court need not find any impropriety lurking behind agency lassitude in order to hold that agency action is unreasonably delayed. ${ }^{207}$

The D.C. Circuit has provided little explanation of these factors or their relationship to one another. ${ }^{208}$ That being said, the court has stated that the first factor is "the most important." 209 The court also explained that the third factor is not as important when most or all of the agency's docket pertains to human health and welfare. ${ }^{210}$ As to the fourth factor, the court has hesitated to compel an agency to prioritize one particular petition, because this "simply moves all others back one space and pro-

543-44 (S.D.N.Y. 2000), aff'd in part, vacated in part sub nom Natural Res. Def. Council, Inc. v. Muszynski, 268 F.3d 91 (2d Cir. 2001).

204. See TRAC, 750 F.2d at 79.

205. See id. at 80 .

206. See id.

207. $I d$. (citations omitted) (internal quotation marks omitted).

208. See Sant'Ambrogio, supra note 202, at 1412 (noting D.C. Circuit has "never attempted to explain the relationship between the factors"); see also Schwartz \& Revesz, supra note 111, at 14 (quoting Sant'Ambrogio, supra note 202, at 1412).

209. See In re Core Commc'ns, Inc., 531 F.3d 849, 855 (D.C. Cir. 2008) ("The first and most important factor is that the time agencies take to make decisions must be governed by a rule of reason." (internal quotation marks omitted)).

210. See Sierra Club v. Thomas, 828 F.2d 783, 798 (D.C. Cir. 1987) (analyzing alleged EPA delay and stating that "although this court has required greater agency promptness as to actions involving interests relating to human health and welfare . . . this factor alone can hardly be considered dispositive when . . . the entire docket of the agency involves issues of this type"). 
Villanova Law Review, Vol. 61, Iss. 5 [2017], Art. 1

duces no net gain." ${ }^{11}$ Finally, the D.C. Circuit has briefly explained the sixth factor, noting that courts are less likely to defer to agencies' stated priorities where it appears the agency has acted in bad faith. ${ }^{212}$

Because applying the TRAC test is so "fact-specific" and flexible, court rulings on agency delay vary widely. ${ }^{213}$ The D.C. Circuit has stated that, while there is no "per se rule" in analyzing agency delay, "a reasonable time for agency action is typically counted in weeks or months, not years." 214 However, a 2014 Administrative Conference of the United States Final Report (the Report) asserts that courts will typically not find an unreasonable delay until several years have passed.215 The Report notes that, while in one case, a delay of "essentially five months" was considered unreasonable, ${ }^{216}$ the Third Circuit also found a six-year delay to be reasonable based on "competing priorities, limited resources, and the need for scientific research."217 However, the Third Circuit reached this decision using a test other than the TRAC test. ${ }^{218}$ The Report also points out that a five-year delay was considered "unreasonable[ ] on its face[,]" a six-year delay was "found to be nothing less than egregious," and a nine-

211. See In re Barr Labs., Inc., 930 F.2d 72, 75 (D.C. Cir. 1991). The court believed it had "no basis for reordering agency priorities," and stated that "[i]n one of the exceptionally rare cases where this court has actually issued an order compelling an agency to press forward with a specific project we were persuaded, largely by agency concessions, that the project backed by plaintiff was plainly more urgent than any that the project's acceleration might [delay]." Id. at 76 (citation omitted) (internal quotation marks omitted); see also Schwartz \& Revesz, supra note 111 , at 14 n.62.

212. See In re Barr Labs., 930 F.2d at 75 ("Where the agency has manifested bad faith, as by singling someone out for bad treatment or asserting utter indifference to a congressional deadline, the agency will have a hard time claiming legitimacy for its priorities.").

213. See Schwartz \& Revesz, supra note 111, at 15.

214. See In re Am. Rivers \& Idaho Rivers United, 372 F.3d 413, 419 (D.C. Cir. 2004) (citing Midwest Gas Users Ass'n v. FERC, 833 F.2d 341, 359 (D.C. Cir. 1987)); see also Midwest Gas Users, 833 F.2d at 359 ("[A] reasonable time for an agency decision could encompass months, occasionally a year or two, but not several years or a decade." (quoting MCI Telecomm. Corp. v. FCC, 627 F.2d 322, 340 (D.C. Cir. 1980) (internal quotation marks omitted))).

215. See Schwartz \& Revesz, supra note 111, at 15 ("More typically, it takes several years before a court will likely find a delay to be unreasonable . . ..").

216. See id. (citing Pub. Citizen v. Heckler, 602 F. Supp. 611, 613 (D.D.C. 1985)). In Heckler, the District Court for the District of Columbia found this delay unreasonable because of a consensus regarding the danger of consuming raw milk. See Heckler, 602 F. Supp. at 613.

217. See Schwartz \& Revesz, supra note 111, at 16 (citing Oil, Chem. \& Atomic Workers Union v. OSHA (OCAWU), 145 F.3d 120, 124 (3d Cir. 1998)); see also generally OCAWU, 145 F.3d 120.

218. See OCAWU, 145 F.3d at 123 (indicating unreasonable delay should be measured by the following factors: (1) length of delay; (2) context of delay as judged by agency's authorizing statute; (3) "the consequences of the agency's delay"; and (4) "any plea of administrative error, inconvenience, [or] practical difficulty" (citing Raymond Proffitt Found. v. EPA, 930 F.Supp. 1088, 1102 (E.D. Pa. 1996))). 
year delay was "objectively extreme." ${ }^{219}$ However, even when a court finds that an agency has failed to act or has delayed unreasonably, it is very unlikely to force the agency to grant the petition; rather, it "typically will ask the agency for a timetable concerning when it can respond, thereby adding additional delay." 220

One critic of the TRAC Test asserts that "courts can use the TRAC analysis to support virtually any conclusion they want to reach," 221 arguing that the TRAC Test "makes no attempt to distinguish between legitimate and illegitimate causes of delay, ... . specific versus broad statutory mandates, or decisions about priorities versus substantive action," and that "[t]he analysis thus ignores the way in which delays undermine the democratic accountability of the administrative state." 222

Contrary to this criticism however, the TRAC Test focuses on the ways agency inaction and unreasonable delay undermine the democratic accountability of administrative agencies, while providing courts with a useful blueprint for evaluating agency inaction and delays. Congress did not codify the exact timeframe for an agency to respond to every type of petition concerning every subject, likely because doing so would have been unworkable and "undesirable." 223 The TRAC test fills the void of the APA's definitional omission and provides courts with the freedom to evaluate all the facts of a case. Thus, the TRAC test is a structure that can guide judicial oversight of agency delays and whether they undermine democratic accountability, or instead evince the existence of excusable delay due to administrative burden or other higher administrative priorities.

While not laid out explicitly, as with agency inaction or unreasonable delay, $\S 553(\mathrm{e})$ petitioners should have the right to challenge some agency denials of petitions under limited circumstances. ${ }^{224}$ The Petition Provision's context and legislative history suggest that denials could be subject to judicial review, ${ }^{225}$ and in reaching its decision in Massachusetts $v$. $E P A,{ }^{226}$ the Supreme Court tacitly acknowledged that petition denials

219. See Schwartz \& Revesz, supra note 111, at $16 \mathrm{nn} .78,79 \& 81$ (citing In re Am. Rivers, 372 F.3d at 419; Fund for Animals v. Norton, 294 F. Supp. 2d 92, 113 (D.D.C. 2003); Pub. Citizen Health Research Grp. v. Chao, 314 F.3d 143, 154, 158 (3d Cir. 2002) (declining to apply TRAC Test)).

220. See Shapiro \& Murphy, supra note 16, at 27.

221. See Sant'Ambrogio, supra note 202, at 1413.

222. See id.

223. See ACUS Recommendation 86-6, supra note 10, at 1.

224. Permitting judicial review of some petition denials is important because “[a]gencies often counter a petitioner's initiation of unreasonable delay litigation by issuing a response (usually a denial), and courts have typically found that such action moots the unreasonable delay complaint." See Schwartz \& Revesz, supra note 111 , at 17 .

225. See 1945 Senate Judiciary Report, supra note 48, at 201 ("The refusal of an agency to grant the petition or to hold rule making proceedings, therefore, would not per se be subject to judicial reversal.").

226. 549 U.S. 497 (2007). 
Villanova Law Review, Vol. 61, Iss. 5 [2017], Art. 1

were justiciable. ${ }^{227}$ The Court has not delineated exactly if and when denials are reviewable, though the lower courts have occasionally permitted such review. ${ }^{228}$ In Natural Resources Defense Council, Inc. v. SEC (NRDC), ${ }^{229}$ the D.C. Circuit observed that review of a petition denial may be available where an agency has undergone "rulemaking proceedings narrowly focused on the particular rule at issue, and has explained in detail its reasons for not adopting [that] rule[ ]." 230 In the same opinion, the court also opined that $\$ 553$ (e) petition denials are generally "ill-suited" for judicial review due to the frequent absence of the aforementioned circumstances. ${ }^{231}$ Legislative history supports the notion that some agency denials of rulemaking petitions are subject to judicial review. A 1945 Report from the Senate Judiciary Committee says that " $[\mathrm{t}]$ he refusal of an agency to grant the petition or to hold rule making proceedings, therefore, would not per se be subject to judicial reversal." ${ }^{232}$ The NRDC court interpreted this language to imply a right to judicial review. ${ }^{233}$

Two years after $N R D C$, the D.C. Circuit stated that it "reject[s] the suggestion that agency denials of requests for rulemaking are exempt from judicial review." 234 The court noted that "an agency may be forced by a reviewing court to institute rulemaking proceedings if a significant factual predicate of a prior decision on the subject (either to promulgate or not to promulgate specific rules) has been removed."235 Other circuits have also observed that agency rulemaking denials are subject to judicial review, albeit at a very deferential level "akin to non-reviewability."236

227. See id. at 533-35 (ordering EPA to revisit and reevaluate $\$ 553$ (e) petition it had previously denied); see also Schwartz \& Revesz, supra note 111, at 29 (discussing Massachusetts v. EPA).

228. See Natural Res. Def. Council, Inc. v. SEC, 606 F.2d 1031, 1036 (D.C. Cir. 1979) ("Because we find the [SEC's] action [in denying a petition] sustainable under the scope of judicial review applicable to this case, we reverse.").

229. 606 F.2d 1031 (D.C. Cir. 1979).

230. See id. at 1047.

231. See id. at 1046 (“An agency's discretionary decision [n] ot to regulate a given activity is inevitably based, in large measure, on factors not inherently susceptible to judicial resolution .... . [and] even if an agency considers a particular problem worthy of regulation, it may determine for reasons lying within its special expertise that the time for action has not yet arrived." (citation omitted)).

232. 1945 SenAte Judiciary Report, supra note 48, at 201.

233. See NRDC, 606 F.2d at 1043 n.14 (“[T] his language implies that judicial review would sometimes be available in the circumstances mentioned.").

234. See WWHT, Inc. v. FCC, 656 F.2d 807, 814 (D.C. Cir. 1981). However, the D.C. Circuit's case law does not "support a general rule that discretionary agency decisions not to adopt rules are reviewable [p]er se," and "the relevant factors incline against reviewability." See NRDC, 606 F.2d at 1047.

235. See WWHT, 656 F.2d at 819.

236. See New York v. U.S. Nuclear Regulatory Comm'n, 589 F.3d 551, 554 (2d Cir. 2009) (citing Cellnet Commc'n, Inc. v. FCC, 965 F.2d 1106, 1111 (D.C. Cir. 1992)); see also Gulf Restoration Network v. McCarthy, 783 F.3d 227, 234 (5th Cir. 2015) (" $[\mathrm{T}]$ he better reading is that these denials are presumptively reviewable, subject to Congressional language clearly to the contrary . . .."); Conservancy of Sw. Fla. v. U.S. Fish \& Wildlife Serv., 677 F.3d 1073 (11th Cir. 2012). 


\section{Conclusion}

Congress's main goals in enacting the APA included "keep[ing] the public currently informed" of agency procedure and rules, permitting "public participation in the rulemaking process," and formulating "uniform standards" of judicial review for agency action or inaction. ${ }^{237}$ To foster some of these goals, the APA included $\$ 553(\mathrm{e})$, which requires agencies to "give all interested person[s] the right to petition for the issuance, amendment, or repeal" of administrative rules. ${ }^{238}$ Under the conflicting and confusing case law, disagreement exists regarding the proper scope and interpretation of the Petition Provision.

While interested persons may submit petitions for legislative rulemaking, courts and the literature disagree as to whether agencies must allow individuals to submit petitions regarding nonlegislative rules. ${ }^{239}$ However, a variety of interpretive tools establish that the guarantee of $\$ 553(\mathrm{e})$ covers all petitions, both legislative and nonlegislative in nature. Even when an agency accepts a petition, there is no consensus regarding which procedures, if any, an agency must follow in considering and responding. If agencies can either refuse to accept petitions regarding nonlegislative rules or indefinitely delay adjudicating petitions for either type of informal rule, they would then have the power to promulgate regulations with the force of law with no public participation or inclusion whatsoever. The Framers of the Constitution and the drafters of the APA envisioned a system where the public should participate in crafting federal law and where courts should be the final arbiters of the legality of those laws. The current system does not hold true to these sentiments.

To ensure that individuals remain able to participate in the legislative process when Congress delegates lawmaking authority to agencies, the APA mandated that agencies accept all petitions for informal rulemaking, both legislative and nonlegislative, and adjudicate each qualifying petition within a reasonable period of time. Agency inaction or unreasonable delay in adjudicating a petition is subject to judicial review, with a standard of review best elucidated by the D.C. Circuit's TRAC test. Denials of such petitions are not per se substantively unreviewable, though such review may be available only in limited circumstances.

The Constitution and the APA amply demonstrate the value that the Framers and Congress placed not only on public participation in the creation of federal law, but also the role of the judiciary in reviewing those laws and the procedures used to promulgate them. ${ }^{240}$ Failure to uphold these

237. See 1947 AG's Manual, supra note 48, at 9; see also Hunnicutt, supra note 20 , at $153-54$.

238. See 5 U.S.C. $\$ 553(e)$ (2012).

239. For an argument that APA $\S 553($ e) applies to both legislative and nonlegislative rules, see Seidenfeld, supra note 9. For an argument that APA $\S 553(\mathrm{e})$ applies only to legislative rules, see Mendelson, supra note 9.

240. See generally Morrison, supra note 18, at 92 ("APA rulemaking as supplemented by judicial review over the procedural and substantive aspects of a final 
rights and values could render individuals excluded altogether from a critical aspect of the nation's process of federal lawmaking.

rule does, as a practical matter, compensate for the absence of political checks that are a central feature of the legislative process."). 